\title{
Sensitivity analysis of an updated bidirectional air-surface exchange model for elemental mercury vapor
}

\author{
X. Wang ${ }^{1,2}$, C.-J. Lin ${ }^{1,3,4}$, and X. Feng ${ }^{1}$ \\ ${ }^{1}$ State Key Laboratory of Environmental Geochemistry, Institute of Geochemistry, \\ Chinese Academy of Sciences, Guiyang, China \\ ${ }^{2}$ University of Chinese Academy of Sciences, Beijing, China \\ ${ }^{3}$ Department of Civil Engineering, Lamar University, Beaumont, TX, USA \\ ${ }^{4}$ College of Environment and Energy, South China University of Technology, Guangzhou, China \\ Correspondence to: C.-J. Lin (jerry.lin@lamar.edu) and X. Feng (fengxinbin@ vip.skleg.cn)
}

Received: 13 June 2013 - Published in Atmos. Chem. Phys. Discuss.: 10 December 2013

Revised: 14 May 2014 - Accepted: 16 May 2014 - Published: 25 June 2014

\begin{abstract}
A box model for estimating bidirectional airsurface exchange of gaseous elemental mercury $\left(\mathrm{Hg}^{0}\right)$ has been updated based on the latest understanding of the resistance scheme of atmosphere-biosphere interface transfer. Simulations were performed for two seasonal months to evaluate diurnal and seasonal variation. The base-case results show that water and soil surfaces are net sources, while vegetation is a net sink of $\mathrm{Hg}^{0}$. The estimated net exchange in a domain covering the contiguous US and part of Canada and Mexico is 38.4 and $56.0 \mathrm{Mg}$ as evasion in the summer and winter month, respectively. The smaller evasion in summer is due to the stronger $\mathrm{Hg}^{0}$ uptake by vegetation. Modeling experiments using a two-level factorial design were conducted to examine the sensitivity of flux response to the changes in physical and environmental parameters in the model. It is shown that atmospheric shear flows (surface wind over water and friction velocity over terrestrial surfaces), dissolved gaseous mercury (DGM) concentration, soil organic and $\mathrm{Hg}$ content, and air temperature are the most influential factors. The positive effect of friction velocity and soil $\mathrm{Hg}$ content on the evasion flux from soil and canopy can be effectively offset by the negative effect of soil organic content. Significant synergistic effects are identified between surface wind and DGM level for water surface, and between soil Hg content and friction velocity for soil surface, leading to $\sim 50 \%$ enhanced flux compared to the sum of their individual effects. The air-foliage exchange is mainly controlled by surface resistance terms influenced by solar irradiation and air temperature. Research in providing geospatial distribution of
\end{abstract}

$\mathrm{Hg}$ in water and soil will greatly improve the flux estimate. Elucidation on the kinetics and mechanism of $\mathrm{Hg}$ (II) reduction in soil/water and quantification of the surface resistances specific to $\mathrm{Hg}$ species will also help reduce the model uncertainty.

\section{Introduction}

Mercury $(\mathrm{Hg})$ is a persistent, bioaccumulative pollutant released into the atmosphere from a variety of anthropogenic and natural sources. The anthropogenic release (2000 $2400 \mathrm{Mg} \mathrm{yr}^{-1}$ ) primarily comes from fossil fuel combustion, waste incineration, metal smelting and cement production (Pacyna et al., 2003, 2006; Streets et al., 2005, 2009; Pirrone et al., 2010). The natural sources include biomass burning, volcanic activities, geological weathering from $\mathrm{Hg}$ enriched substrates and so-called re-emission (i.e., the emission of previously deposited $\mathrm{Hg}$ ) at the atmosphere-biosphere interface (Gustin et al., 2008; Mason and Sheu, 2002). While the anthropogenic emissions have been estimated and continuously updated with reasonable consistency since the 1990s, the estimates for natural emissions have been highly uncertain (1500-5207 $\mathrm{Mg} \mathrm{yr}^{-1}$ ), primarily due to a lack of understanding in the air-surface exchange of $\mathrm{Hg}^{0}$. Since the natural release can account for up to two-thirds of global mercury input to the atmosphere (Friedli et al., 2009; Pirrone et al., 2010), better quantification of the mass input is critical 
in assessing the global biogeochemical cycling of mercury (Lindberg et al., 2007).

Air-surface exchange is an important component in atmospheric mercury modeling for estimating $\mathrm{Hg}^{0}$ evasion and deposition over soil, water and vegetation. For terrestrial surfaces, the soil $\mathrm{Hg}$ evasion has been calculated using the statistical relationships obtained from the measured $\mathrm{Hg}^{0}$ flux and observed environmental factors such as temperature, solar irradiance, leaf area index and $\mathrm{Hg}$ content (Bash et al., 2004; Gbor et al., 2006; Lin et al., 2005; Shetty et al., 2008; Xu et al., 1999; Selin and Jacob, 2008; Smith-Downey et al., 2010). Such an approach oversimplifies the role of environmental factors in the exchange process because $\mathrm{Hg}^{0}$ flux was measured in a limited number of locations where the environmental parameters (e.g., soil properties and meteorology) are specific to those sites. In addition, most of these models treat vegetation as a net evasion source of $\mathrm{Hg}^{0}$, which is inconsistent with later assessments that suggest vegetation to be a net sink (Gustin et al., 2008; Hartman et al., 2009). Recent isotopic tracer studies have shown that plant roots serve as a barrier that prevents translocation of inorganic $\mathrm{Hg}$ in soil to other parts of plants (Cui et al., 2014). It has also been suggested that $\mathrm{Hg}$ absorbed on foliage can be transported to stems and roots (Yin et al., 2013).

To better represent the surface process, algorithms parameterizing the transport resistances at soil and foliage interfaces have been developed to calculate the multilayered, bidirectional flux by the gradient between an ambient $\mathrm{Hg}$ level and a "compensation point" inferred from the surface characteristics (Bash, 2007, 2010; Scholtz et al., 2003; Zhang et al., 2009a; Sutton et al., 2007). Such an approach is more scientifically sound and mathematically robust. The model results were also more consistent with those from isotopic tracer studies (Bash, 2010). However, the complicated parameterization makes it difficult to understand the relative importance of each parameter on the simulated flux. There are also multiple model assumptions on the model variables that lack field data for verification. Although the model results can be constrained by air concentration and wet deposition, the assumptions could increase the uncertainty of model estimates and limit the improvement of model algorithms.

The objectives of this study are to present an updated $\mathrm{Hg}^{0}$ air-surface exchange model and to quantitatively examine the relative importance of the physical and environmental variables implemented in the model. Coupled with the latest understanding in the partitioning and mass transfer at different atmosphere-biosphere interfaces, we integrated the bidirectional air-surface exchange model (Bash, 2007, 2010) and the surface resistance schemes of $\mathrm{Hg}$ dry deposition and photochemical reaction (Zhang et al., 2003, 2009a; Lin et al., 2006) for quantifying the air-surface exchange of $\mathrm{Hg}^{0}$. Two monthly (summer and winter) simulations were performed to investigate the seasonal and diurnal variability of the modelestimated flux. A systematic set of sensitivity simulations using a multi-step factorial design of experiments was per- formed to investigate the effect of significant model parameters and their interconnections. Based on the sensitivity results, processes that control $\mathrm{Hg}^{0}$ air-surface exchange over different natural surfaces are discussed and research needs for future model improvement are proposed.

\section{Methods}

\subsection{Model description}

The total air-surface exchange is the sum of $\mathrm{Hg}^{0}$ fluxes from water, soil (including bare lands and soil under the canopy) and foliage surfaces. The direction (evasion or deposition) of the flux is driven by the gradient between atmospheric $\mathrm{Hg}^{0}$ concentration and a compensation point that represents the $\mathrm{Hg}^{0}$ concentration at the interface between the atmosphere and the surface of interest. The magnitude of the flux is determined by the ratio of concentration gradient to surface resistance (for terrestrial surfaces) or by the product of overall mass transfer coefficient and concentration gradient (for water surfaces). The nomenclature and dimension of the entire set of model variables are detailed in Table 1 . The parameterization of each model component is briefly described below.

\subsection{Air-water exchange}

The flux over fresh water and oceanic surfaces, $F_{\mathrm{w}}$, is calculated using a two-film mass transfer model with the transfer rate limited by the diffusion in the water boundary layer (Poissant et al., 2000):

$F_{\mathrm{w}}=K_{\mathrm{w}}\left(C_{\mathrm{w}}-\frac{C_{\mathrm{atm}}}{H_{\mathrm{w}}}\right)$,

where $K_{\mathrm{w}}$ is the overall mass transfer coefficient estimated by the wind speed at $10 \mathrm{~m}$ above water surface and the mass transfer ratio of $\mathrm{CO}_{2} / \mathrm{Hg}$ across the air-water interface (Shetty et al., 2008), $C_{\mathrm{w}}$ is the dissolved gaseous mercury (DGM) concentration in surface water, $H_{\mathrm{w}}$ is the dimensionless Henry's law constant. $K_{\mathrm{w}}$ and $H_{\mathrm{w}}$ are calculated using formulation described earlier (Poissant et al., 2000; Lin and Tao, 2003).

\subsection{Air-terrestrial exchange}

The terrestrial system is divided into two categories: the canopy biomes (leaf area index, LAI $>0$ ) and the bare lands $(\mathrm{LAI}=0$, referring to sparsely vegetated land, bare tundra and snow/ice surfaces). The total flux from the canopy is made up of the air-soil exchange flux and the air-foliage exchange flux (air-stomata and air-cuticle). Over the canopy system, a multi-layer canopy resistance scheme modified after Bash (2010) and Zhang et al. (2003) was applied (Fig. 1). Compared to the earlier mechanistic schemes, this model also (1) includes the foliage storage effect, (2) considers photochemical reduction on foliage, and (3) updates the 
Table 1. Model variables and units in the base-case simulation.

\begin{tabular}{|c|c|c|}
\hline Term & Description & Value or units \\
\hline$F_{\mathrm{W}}$ & Flux from water bodies & $\operatorname{ng~m}{ }^{-2} h^{-1}$ \\
\hline$K_{\mathrm{W}}$ & Mass transfer coefficient of mercury through water layer & $\mathrm{m} \mathrm{h}^{-1}$ \\
\hline$C_{\mathrm{w}}$ & DGM concentration & $40 \mathrm{ng} \mathrm{m}^{-3}$ water $^{\mathrm{a}}$ \\
\hline$H_{\mathrm{w}}$ & Henry's law constant under water conditions & dimensionless \\
\hline$F_{\text {cnp }}$ & The flux over canopy biomes & $\mathrm{ng} \mathrm{m}^{-2} \mathrm{~h}^{-1}$ \\
\hline$\Delta t$ & Time duration & s \\
\hline$R_{\mathrm{a}}$ & Aerodynamic resistance & $\mathrm{s} \mathrm{m}^{-1}$ \\
\hline$R_{\mathrm{b}}$ & Quasi-laminar sub-layer resistance & $\mathrm{s} \mathrm{m}^{-1}$ \\
\hline$C_{\text {atm }}$ & Atmospheric $\mathrm{Hg}$ concentration & $n g \mathrm{~m}^{-3}$ \\
\hline$\chi_{\mathrm{cnp}}$ & The total compensation point & $n g m^{-3}$ \\
\hline$\chi_{c}$ & Cuticular interfaces compensation point & $n g \mathrm{~m}^{-3}$ \\
\hline$\chi_{\mathrm{s}}$ & Stomatal interfaces compensation point & $n g \mathrm{~m}^{-3}$ \\
\hline$\chi_{\mathrm{g}}$ & Soil interfaces compensation point & $\mathrm{ng} \mathrm{m}^{-3}$ \\
\hline$R_{\mathrm{c}}$ & Cuticular resistance & $\mathrm{s} \mathrm{m}^{-1}$ \\
\hline$R_{\mathrm{S}}$ & Stomatal resistance & $\mathrm{s} \mathrm{m}^{-1}$ \\
\hline$R_{\mathrm{g}}$ & Soil diffusion resistance & $\mathrm{s} \mathrm{m}^{-1}$ \\
\hline$R_{\mathrm{ac}}$ & In-canopy aerodynamic resistance & $\mathrm{s} \mathrm{m}^{-1}$ \\
\hline$F_{\text {bls }}$ & The flux from bare land soil & $n g m^{-3}$ \\
\hline$\left[\mathrm{Hg}^{0}\right]_{\mathrm{Sl}}$ & Elemental mercury content bound to organic matter & $\operatorname{ng~g}^{-1}$ soil \\
\hline$H$ & Henry's law constant in soil condition & dimensionless \\
\hline$f_{\mathrm{oc}}$ & Fraction of organic carbon in topsoil $(0-5 \mathrm{~cm})$ & $2 \%(\text { dimensionless })^{\mathrm{b}}$ \\
\hline$K_{\mathrm{Oc}}$ & Soil organic carbon to water partitioning coefficient & $\mathrm{m}^{3}$ water $\mathrm{g}^{-1}$ organic carbon \\
\hline$[\mathrm{Hg}(\mathrm{II})]_{\mathrm{sl}}$ & $\mathrm{Hg}(\mathrm{II})$ content in the soil & $90 \mathrm{ng} \mathrm{g}^{-1}$ soil $^{\mathrm{c}}$ \\
\hline$R_{\mathrm{g}\left(\mathrm{SO}_{2}\right)}$ & $\mathrm{SO}_{2}$ soil diffusion resistance & $\mathrm{s} \mathrm{m}^{-1}$ \\
\hline$R_{\mathrm{g}\left(\mathrm{O}_{3}\right)}$ & $\mathrm{O}_{3}$ soil diffusion resistance & $\mathrm{s} \mathrm{m}^{-1}$ \\
\hline$\alpha_{\mathrm{Hg}^{0}}$ & $\mathrm{Hg}^{0}$ scaling factor basing on $\mathrm{SO}_{2}$ & 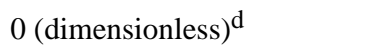 \\
\hline$\beta_{\mathrm{Hg}^{0}}$ & $\mathrm{Hg}^{0}$ scaling factor basing on $\mathrm{O}_{3}$ & 0.1 (dimensionless) $^{\mathrm{e}}$ \\
\hline LAP & Leaf-air partitioning coefficient for $\mathrm{Hg}^{0}$ between leaves and air & 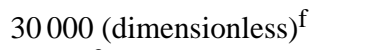 \\
\hline$\left[\mathrm{Hg}_{\mathrm{c}}^{0}\right]$ & $\mathrm{Hg}^{0 \text { content }}$ bound to foliar cuticular surface & $\mathrm{ng} \mathrm{m}^{-3}$ leaf \\
\hline$\left[\mathrm{Hg}_{\mathrm{c}}^{\mathrm{II}+}\right]$ & Newly dry deposited $\mathrm{Hg}(\mathrm{II})$ residing on cuticular surfaces & $n g m^{-2}$ leaf \\
\hline$\left[\mathrm{Hg}_{\mathrm{c}, \mathrm{DD}}^{\mathrm{II}+}\right]$ & The total dry deposited $\mathrm{Hg}$ (II) loading on cuticular compartment & $n g m^{-2}$ leaf \\
\hline$\left[\mathrm{Hg}_{\mathrm{w}}^{\mathrm{lI}}+\mathrm{+}\right.$ & $\mathrm{Hg}(\mathrm{II})$ leaf wash concentration & $0.04 \mathrm{ng} \mathrm{m}^{-2}$ leaf $\mathrm{g}$ \\
\hline$f_{\text {rxn }}$ & Fraction of $\mathrm{Hg}(\mathrm{II})$ potentially photoreduced to $\mathrm{Hg}^{0}$ & dimensionless \\
\hline$f_{\text {fixed }}$ & Fraction of $\mathrm{Hg}(\mathrm{II})$ fixed into tissue & dimensionless \\
\hline$T_{1}$ & Leaf thickness & $0.000152 \mathrm{~m}^{\mathrm{h}}$ \\
\hline$\left[\mathrm{Hg}_{\mathrm{S}}^{0}\right]$ & Dissolved elemental mercury in stomatal compartment & ng $\mathrm{m}^{-3}$ leaf \\
\hline$\left[\mathrm{Hg}_{\mathrm{s}, \mathrm{DD}}^{0}\right]$ & Deposited $\mathrm{Hg}^{0}$ concentration stored inside stomatal compartment & $0.39 \mathrm{ng} \mathrm{m}^{-2}$ leaf $^{-1 \mathrm{i}}$ \\
\hline$R_{\mathrm{St}}$ & Resistance associating stomata apertures & $\mathrm{s} \mathrm{m}^{-1}$ \\
\hline$R_{\text {me }}$ & Resistance associating mesophyll reservoir & $\mathrm{s} \mathrm{m}^{-1}$ \\
\hline$W_{\text {st }}$ & Fraction of stomatal blocking under wet condition & dimensionless \\
\hline
\end{tabular}

${ }^{a}$ Value for base-case simulation, Xu et al. (1999); ${ }^{\mathrm{b}}$ for $0-20 \mathrm{~cm}$ topsoil, the bulk density is $1.1-1.3 \mathrm{~g} \mathrm{~cm}^{-3}$ and organic carbon content is $3.3 \mathrm{~kg} \mathrm{~m}^{-2}$ in the US (Calhoun et al., 2001; Guo et al., 2006), so assuming $f_{\text {oc }}$ is $2 \%$ in the $0-5 \mathrm{~cm}$ topsoil; ${ }^{\mathrm{c}}$ value for base-case simulation, Bash (2010); ${ }^{\mathrm{d}}$ based on the negligible solubility (Henry's constant $=0.139 \mathrm{M} \mathrm{atm}^{-1}$ ) and chemical inertness (Zhang et al., 2009b, 2012); ${ }^{\mathrm{e}}$ Zhang et al. (2012); ${ }^{\mathrm{f}}$ Rutter et al. (2011a); ${ }^{\mathrm{g}}$ value for base-case simulation, Frescholtz et al. (2003); ${ }^{\mathrm{h}}$ value for base-case simulation, Abrams and Kubiske (1990); ${ }^{\text {i }}$ value for base-case simulation, Poissant et al. (2008).

resistance terms. The flux over canopy biomes, $F_{\text {cnp }}$, is estimated as

$$
F_{\mathrm{cnp}}=\frac{\Delta t}{\left(R_{\mathrm{a}}+R_{\mathrm{b}}\right)}\left(\chi_{\mathrm{cnp}}-C_{\mathrm{atm}}\right)
$$

where $\Delta t$ is the time duration, $R_{\mathrm{a}}$ is the aerodynamic resistance, $R_{\mathrm{b}}$ is the quasi-laminar layer resistance and $C_{\mathrm{atm}}$ is the atmospheric $\mathrm{Hg}$ concentration. $R_{\mathrm{a}}$ and $R_{\mathrm{b}}$ are calculated according to Marsik et al. (2007). $\chi_{\mathrm{cnp}}$ is the overall compensation point parameterized as a weighted average at the 


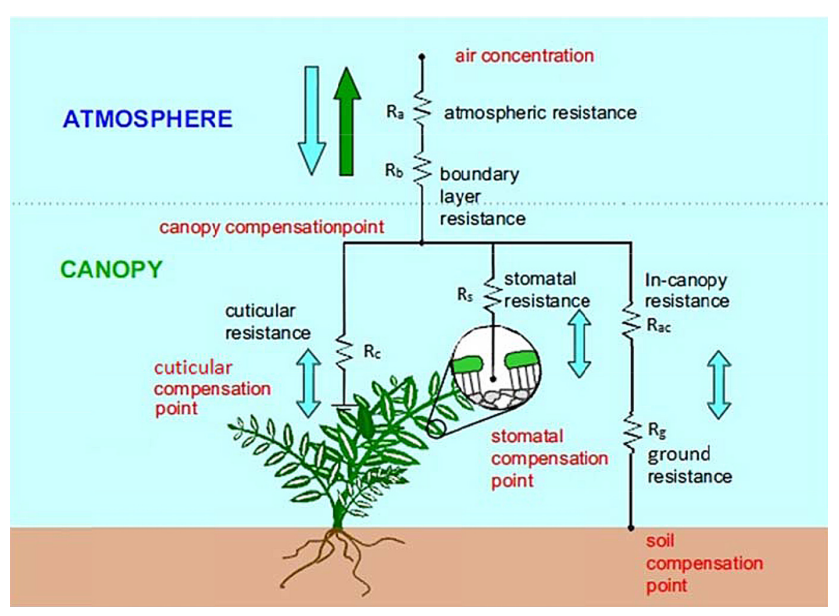

Figure 1. Resistance scheme implemented in the air-surface exchange model following Sutton et al. (2007) and Zhang et al. (2009a).

air-cuticle, air-stomata and air-soil interfaces as illustrated in Fig. 1 (Bash, 2010; Zhang et al., 2009a):

$\chi_{\mathrm{cnp}}=\frac{\frac{\chi_{\mathrm{c}}}{R_{\mathrm{c}}}+\frac{\chi_{\mathrm{s}}}{R_{\mathrm{s}}}+\frac{\chi_{\mathrm{g}}}{R_{\mathrm{g}}+R_{\mathrm{ac}}}+\frac{C_{\mathrm{atm}}}{R_{\mathrm{a}}+R_{\mathrm{b}}}}{\frac{1}{R_{\mathrm{c}}}+\frac{1}{R_{\mathrm{s}}}+\frac{1}{R_{\mathrm{g}}+R_{\mathrm{ac}}}+\frac{1}{R_{\mathrm{a}}+R_{\mathrm{b}}}}$,

where $\chi_{\mathrm{c}}$ is the cuticular compensation point, $\chi_{\mathrm{s}}$ is the stomatal compensation point, $\chi_{\mathrm{g}}$ is the soil compensation point, $R_{\mathrm{C}}$ is the cuticular resistance, $R_{\mathrm{S}}$ is the stomatal resistance, $R_{\mathrm{g}}$ is the soil diffusion resistance, and $R_{\mathrm{ac}}$ is the in-canopy aerodynamic resistance. The individual compensation points are described by Eqs. (6), (9) and (15).

\subsubsection{Air-soil exchange}

In the absence of vegetation (when $\mathrm{LAI}=0$ ), the flux from bare lands $\left(F_{\text {bls }}\right)$ can be estimated as

$F_{\mathrm{bls}}=\frac{\Delta t}{R_{\mathrm{a}}+R_{\mathrm{b}}+R_{\mathrm{g}}}\left(\chi_{\mathrm{g}}-C_{\mathrm{atm}}\right)$.

In the presence of vegetation (when $\mathrm{LAI}>0$ ), the flux from soil under canopy $\left(F_{\mathrm{g}}\right)$ is calculated as

$F_{\mathrm{g}}=\frac{\Delta t}{R_{\mathrm{g}}+R_{\mathrm{ac}}}\left(\chi_{\mathrm{g}}-\chi_{\mathrm{cnp}}\right)$,

where $R_{\text {ac }}$ accounts for the resistance of gas diffusion from ground to the lower canopy and is assumed to be common for all gaseous species (Zhang et al., 2002b).The compensation point at air-soil interface $\left(\chi_{\mathrm{g}}\right)$ can be expressed as (Bash, 2010)

$\chi_{\mathrm{g}}=\frac{\left[\mathrm{Hg}^{0}\right]_{\mathrm{sl}} H}{f_{\mathrm{oc}} K_{\mathrm{oc}}}$,

where $\left[\mathrm{Hg}^{0}\right]_{\mathrm{sl}}$ is the concentration of $\mathrm{Hg}^{0}$ bound to soil, calculated as a reduction product of $\mathrm{Hg}$ (II) using soil $\mathrm{Hg}$ content and a pseudo-first-order rate constant related to solar irradiance (Gustin et al., 2002). $H$ is Henry's constant parameterized following Andersson et al. (2008). $f_{\text {oc }}$ is the fraction of organic carbon in surface soil $(0-5 \mathrm{~cm}) . K_{\mathrm{oc}}$ is the partition coefficient of $\mathrm{Hg}^{0}$ between soil organic carbon and water.

$R_{\mathrm{g}}$ is the $\mathrm{Hg}^{0}$ diffusion resistance over a ground surface (soil, ice/snow) (Zhang et al., 2002b):

$\frac{1}{R_{\mathrm{g}}}=\frac{\alpha_{\mathrm{Hg}^{0}}}{R_{\mathrm{g}\left(\mathrm{SO}_{2}\right)}}+\frac{\beta_{\mathrm{Hg}^{0}}}{R_{\mathrm{g}\left(\mathrm{O}_{3}\right)}}$,

where $R_{\mathrm{g}\left(\mathrm{SO}_{2}\right)}$ and $R_{\mathrm{g}\left(\mathrm{O}_{3}\right)}$ are the diffusion resistances of $\mathrm{SO}_{2}$ and $\mathrm{O}_{3}, \alpha_{\mathrm{Hg}^{0}}$ is the $\mathrm{Hg}^{0}$ scaling factor based on $\mathrm{SO}_{2}$, and $\beta_{\mathrm{Hg}^{0}}$ is $\mathrm{Hg}^{0}$ scaling factor based on $\mathrm{O}_{3}$. The formulation of $R_{\mathrm{g}\left(\mathrm{SO}_{2}\right)}$ and $R_{\mathrm{g}\left(\mathrm{O}_{3}\right)}$ has been described previously (Zhang et al., 2003).

\subsubsection{Air-cuticle exchange}

Air-cuticle exchange flux is calculated as (Bash, 2010)

$F_{\mathrm{c}}=\frac{\Delta t}{R_{\mathrm{c}}}\left(\chi_{\mathrm{c}}-\chi_{\mathrm{cnp}}\right)$,

$\chi_{\mathrm{c}}=\frac{\left[\mathrm{Hg}_{\mathrm{c}}^{0}\right]}{\mathrm{LAP}}$,

where LAP denotes the leaf-air partitioning coefficient for $\mathrm{Hg}^{0}$ (Rutter et al., 2011) and $\left[\mathrm{Hg}_{\mathrm{c}}^{0}\right]$ is the concentration of $\mathrm{Hg}^{0}$ bound to foliar cuticular surface, calculated as the photoreduction product of a fraction of newly deposited $\mathrm{Hg}$ (II) on foliar interfaces (Graydon et al., 2009):

$$
\begin{aligned}
& {\left[\mathrm{Hg}_{\mathrm{c}}^{0}\right]=f_{\mathrm{rxn}}\left[\mathrm{Hg}_{\mathrm{c}, \mathrm{DD}}^{\mathrm{II}+}\right],} \\
& {\left[\mathrm{Hg}_{\mathrm{c}}^{\mathrm{II}+}\right]=\left(1-f_{\mathrm{rxn}}-f_{\text {fixed }}\right)\left[\mathrm{Hg}_{\mathrm{c}, \mathrm{DD}}^{\mathrm{II}+}\right],} \\
& {\left[\mathrm{Hg}_{\mathrm{c}}^{\mathrm{II}+}\right]=\frac{\left[\mathrm{Hg}_{\mathrm{w}}^{\mathrm{II}+}\right]}{T_{1}},}
\end{aligned}
$$

where $\left[\mathrm{Hg}_{\mathrm{c}, \mathrm{DD}}^{\mathrm{II}+}\right]$ is the concentration loading of total dry deposited $\mathrm{Hg}(\mathrm{II})$ on cuticle, $\left[\mathrm{Hg}_{\mathrm{c}}^{\mathrm{II}+}\right]$ is the concentration of the deposited $\mathrm{Hg}(\mathrm{II})$ residing on cuticular surfaces, $\left[\mathrm{Hg}_{\mathrm{w}}^{\mathrm{II}+}\right]$ is the concentration of $\mathrm{Hg}$ (II) that can be washed off from leaves, $f_{\text {rxn }}$ is the fraction of $\mathrm{Hg}$ (II) that can be photoreduced, $f_{\text {fixed }}$ is the fraction of $\mathrm{Hg}$ (II) fixed into tissue and not available for re-emission or wash-off, and $T_{1}$ is the leaf thickness. $f_{\text {rxn }}$ and $f_{\text {fixed }}$ are parameterized following Smith-Downey et al. (2010). $R_{\mathrm{c}}$ is the cuticular resistance calculated as (Zhang et al., 2002b)

$$
\frac{1}{R_{\mathrm{c}}}=\frac{\alpha_{\mathrm{Hg}^{0}}}{R_{\mathrm{c}\left(\mathrm{SO}_{2}\right)}}+\frac{\beta_{\mathrm{Hg}^{0}}}{R_{\mathrm{c}\left(\mathrm{O}_{3}\right)}} .
$$

\subsubsection{Air-stomata exchange}

The air-stomata exchange flux is estimated as (Bash, 2010)

$$
F_{\mathrm{s}}=\frac{\Delta t}{R_{\mathrm{s}}}\left(\chi_{\mathrm{s}}-\chi_{\mathrm{cnp}}\right)
$$


$\chi_{\mathrm{s}}=\frac{\left[\mathrm{Hg}_{\mathrm{s}}^{0}\right]}{\mathrm{LAP}}$.

It is assumed that the uptake of $\mathrm{Hg}$ species through stomata is predominantly $\mathrm{Hg}^{0}$ due to its abundance in the atmosphere (Capiomont et al., 2000; Millhollen et al., 2006; Stamenkovic and Gustin, 2009). As such, the dissolved $\mathrm{Hg}^{0}$ in the stomatal compartment, $\left[\mathrm{Hg}_{\mathrm{s}}^{0}\right]$, can be formulated as

$\left[\mathrm{Hg}_{\mathrm{s}}^{0}\right]=\left(1-f_{\text {fixed }}\right)\left[\mathrm{Hg}_{\mathrm{s}, \mathrm{DD}}^{0}\right]$

where $\left[\mathrm{Hg}_{\mathrm{s}, \mathrm{DD}}^{0}\right]$ is the concentration of newly deposited $\mathrm{Hg}^{0}$ stored in the stomatal compartment. The overall stomatal resistance is calculated as (Zhang et al., 2002b)

$R_{\mathrm{S}}=\frac{R_{\mathrm{st}}+R_{\mathrm{me}}}{1-W_{\mathrm{st}}}$,

where $R_{\mathrm{st}}$ is the resistance associated with stomata, $R_{\mathrm{me}}$ is resistance associated with mesophyll reservoir, and $W_{\text {st }}$ is the fraction of stomatal blocking under wet condition. The detailed formulation of $R_{\mathrm{st}}$ and $R_{\mathrm{me}}$ and $W_{\mathrm{st}}$ can be found elsewhere (Zhang et al., 2002b, 2003, 2012).

\subsection{Modeling experiments for sensitivity analysis}

To explore the sensitivity of model response to the changes in model parameters, the model results obtained by varying the input values of model parameters were compared systematically. This was accomplished by a technique called two-level factorial design of experiments, which estimates the change of model response (i.e., the simulated air-surface exchange flux of $\mathrm{Hg}^{0}$ ) caused by the changes in model parameters at two levels (i.e., a high and a low typical value). Additional discussion on the application of factorial design of experiments is provided in the Supplement. In short, the values of model parameters were varied individually (i.e., changing one input value of a model parameter at a time) and in combinations (i.e., simultaneously changing the input values of two or more model parameters) at the two selected levels. Then the $\mathrm{Hg}^{0}$ exchange fluxes at the changed input values were calculated and compared to estimate the sensitivity. This method is statistically robust, and therefore the synergistic and antagonistic interactions among model parameters can be estimated with indications of statistical significance. The studied parameters include both physical and environmental factors. Their respective experimental levels are shown in Tables 2-4. The principle of factor sparsity (Myers et al., 2009) states that the main factor effects and lowerorder interactions dominate most system responses (i.e., it is unlikely for three or more predominant factors influencing the system response simultaneously). Therefore, the effect of interaction terms higher than second order was not considered.

For the water surface, there are four parameters (factors) driving the model simulation (Table 2). Therefore, there are $16\left(2^{4}\right)$ possible combinations of input parameter values at two levels. In this case, the model was run 16 times (so-called "full factorial design" because all possible experimental runs are analyzed), and the data were compared for identifying the significant factors. For the bare lands, there are 2048 possible combinations at two levels ( $2^{11}$ for 11 parameters). In this case, we first selected 32 runs (so-called $2^{11-6}$ "fractional design" because only a fraction of all possible experimental runs is analyzed) that allowed for statistical analysis of all single-factor effects and two-factor interactions in order to screen out the significant factors. After this initial screening, a two-level full factorial design was applied to the five most significant factors based on a $95 \%$ confidence level to assess the sensitivity (the results of the $2^{11-6}$ design are shown in the Supplement). For the canopy ecosystem, there are 15 model factors (Table 4). In this case, a $2^{15-9}$ fractional design (64 runs) was first utilized to identify 11 predominant factors. Then a successive $2^{11-6}$ design was applied to obtain the five most significant factors, whose sensitivity was assessed using a $2^{5}$ full factorial design (the results of the $2^{15-9}$ and $2^{11-6}$ designs are shown in the Supplement). The sensitivity results were obtained from the final full factorial design for watersheds, bare lands and canopy ecosystems. The data analysis of the factorial experiments was conducted using Minitab ${ }^{\circledR} 16$ professional version.

\subsection{Model configuration and data}

The modeling domain is in Lambert conformal projection covering mainly the contiguous United States (CONUS), with $156 \times 118$ grid cells at $36 \mathrm{~km}$ spatial resolution. Hourly meteorological data were prepared using the Weather Research and Forecasting (WRF) model version 3.4 with the Noah land surface model. The model algorithms were coded in FORTRAN 90 and Network Common Data Form (NetCDF) version 4.1. The gridded model results were visualized by the Visualization Environmental for Rich Data Interpretation (VERDI) version 1.4.

A base-case simulation was performed in a summer and a winter month (August and December 2009) to evaluate the seasonal and diurnal variability of the air-surface exchange. The base case refers to the modeling utilizing the values listed in Table 1 with the meteorological parameters extracted from WRF output. In the simulation, the atmospheric $\mathrm{Hg}^{0}$ concentration retrieved from the output of the $\mathrm{Hg}$ extension of Community Multi-scale Air Quality modeling system (CMAQ-Hg) version 4.6 for the same modeling period was applied to represent the air concentration of $\mathrm{Hg}^{0}$. The simulation does not directly incorporate the feedback of the air-surface exchange to the air concentration. However, for a regional model domain (CONUS), natural evasion and deposition of $\mathrm{Hg}^{0}$ does not significantly modify the ambient concentration (Lin et al., 2005; Gbor et al., 2006) since the time required for air turnover is relatively short (typically 3 4 days) and the air concentration of $\mathrm{Hg}$ is mainly controlled 
Table 2. Examined model variables and the experimental levels of factorial design for air-water exchange.

\begin{tabular}{|c|c|c|c|}
\hline Term & Description & Low level & High level \\
\hline$T$ & Sea surface temperature $\left({ }^{\circ} \mathrm{C}\right)$ & $-2^{\mathrm{a}}$ & $35^{\mathrm{a}}$ \\
\hline GEM & Air $\mathrm{Hg}^{0}$ concentration $\left(\mathrm{ng} \mathrm{m}^{3}\right)$ & $1.0^{\mathrm{b}}$ & $2.0^{\mathrm{b}}$ \\
\hline DGM & Dissolved $\mathrm{Hg}^{0}$ concentration in surface water $\left(\mathrm{ng} \mathrm{m}^{-3}\right)$ & $15^{\mathrm{c}}$ & $240^{\mathrm{c}}$ \\
\hline$W$ & Wind speed at $10 \mathrm{~m}$ above water surface $\left(\mathrm{m} \mathrm{s}^{-1}\right)$ & $0.001^{\mathrm{d}}$ & $20^{\mathrm{d}}$ \\
\hline
\end{tabular}

by the boundary conditions (Pongprueksa et al., 2008). In the model experiments, the concentration of $\mathrm{Hg}^{0}$ was tested as a sensitivity parameter.

\section{Results and discussion}

\subsection{Results of base-case simulations}

The model estimates a net emission of $38.4 \mathrm{Mg}$ in the summer month $(16.6 \mathrm{Mg}$ from water, $45.0 \mathrm{Mg}$ from soil and $-23.2 \mathrm{Mg}$ from foliage) and $56.0 \mathrm{Mg}$ in the winter month (33.9 Mg from water, $29.5 \mathrm{Mg}$ from soil and $-7.4 \mathrm{Mg}$ from foliage) for the entire domain. The evasion from water bodies accounts for $\sim 50 \%$ of the total natural emission (the cumulative net release of $\mathrm{Hg}^{0}$ caused by the air-surface exchange process) because of the large water areal coverage in the domain $(59 \%)$. Vegetation represents a net sink, which is different from earlier estimates using the evapotranspiration approach (Bash et al., 2004; Shetty et al., 2008) but consistent with recent observational studies (Gustin et al., 2008; Stamenkovic and Gustin, 2009). For the terrestrial system, the total emission is $43.9 \mathrm{Mg}$ in 2 months. Assuming the annual emission is 5-6 times of the 2-monthly sum and excluding the emission from Canada, Mexico and Caribbean lands, the model-estimated annual emission in the contiguous US is $118-141 \mathrm{Mg} \mathrm{yr}^{-1}$, comparable to the recent estimates (95-150 $\mathrm{Mg} \mathrm{yr}^{-1}$ ) using flux scaling methods (Ericksen et al., 2006; Hartman et al., 2009; Zehner and Gustin, 2002).

\subsubsection{Air-water exchange}

Over water surface, the mean simulated flux is 1.6 and $3.1 \mathrm{ng} \mathrm{m}^{-2} \mathrm{~h}^{-1}$ in the summer and winter month (Figs. 2a and $3 \mathrm{a}$ ), respectively. Water bodies in the domain are net sources, producing fluxes typically in the range of 1$4 \mathrm{ng} \mathrm{m}^{-2} \mathrm{~h}^{-1}$, similar to earlier measurements (Mason et al., 2001a; Andersson et al., 2011). The spatial distribution is primarily driven by the surface wind speed. Temperature, air $\mathrm{Hg}^{0}$ and DGM concentration play a much less significant role because a constant DGM was assumed $\left(40 \mathrm{ng} \mathrm{m}^{-3}\right)$ and the $\mathrm{Hg}^{0}$ level over water was in a narrow range (1.4$\left.1.8 \mathrm{ng} \mathrm{m}^{-3}\right)$. The Pearsons's correlation coefficient $(r)$ be- tween flux and wind speed is much stronger than the value between flux and temperature (0.56 vs. 0.18$)$. The flux in the winter month is greater because of stronger winds in the northeastern corner of the domain. The emission flux does not show clear diurnal variation in both months because wind speed is the most dominant factor (Fig. 4a).

\subsubsection{Air-soil exchange}

Soil surfaces have been suggested to be a net source of $\mathrm{Hg}$ (Gustin et al., 2008; Hartman et al., 2009), which is also shown in the base-case model results (Figs. 2 and 3). The mean flux from bare lands $\left(0.7\right.$ and $0.6 \mathrm{ng} \mathrm{m}^{-2} \mathrm{~h}^{-1}$ in the summer and winter month) is lower than the value from soil under the canopy ( 4.3 and $2.7 \mathrm{ng} \mathrm{m}^{-2} \mathrm{~h}^{-1}$ ) because of the land use classification. The bare lands in the domain include sparsely vegetated land, bare ground tundra and snow/ice lands. The flux contribution from such land use types is largely from the southern portion of the domain. The simulated flux from soil under canopy is comparable to those reported at background sites, $-0.1-7 \mathrm{ng} \mathrm{m}^{-2} \mathrm{~h}^{-1}$ (Ericksen et al., 2006; Kuiken et al., 2008a, b; Carpi and Lindberg, 1998).

The simulated $\mathrm{Hg}^{0}$ flux from soil under canopy is controlled by the degree of vegetation coverage (LAI), air temperature, friction velocity, air $\mathrm{Hg}$ concentration and solar irradiation. In the summer month, the flux in eastern US is lower due to heavy vegetation coverage that increases the incanopy aerodynamic resistance ( $\left.R_{\mathrm{ac}}\right)$ (Zhang et al., 2002a). Higher flux occurs in the central and western US because of the smaller LAI and higher air temperature (Figs. 2c and S8 in the Supplement). In the winter month, the higher air temperature and longer sunlit hours cause the higher flux in the south (Fig. 3c, S8 in the Supplement). Among the environmental parameters, LAI has the greatest influence on the estimated flux $(r=0.45)$. The spatially average soil flux for the entire domain shows a typical diurnal variation caused by air temperature and solar irradiance (Gabriel et al., 2006). The detailed impact of the model variables is discussed in the sensitivity analysis.

\subsubsection{Air-foliage exchange}

Vegetation represents a net sink of $\mathrm{Hg}^{0}$ in the base-case simulations. The mean simulated air-foliage exchange is 


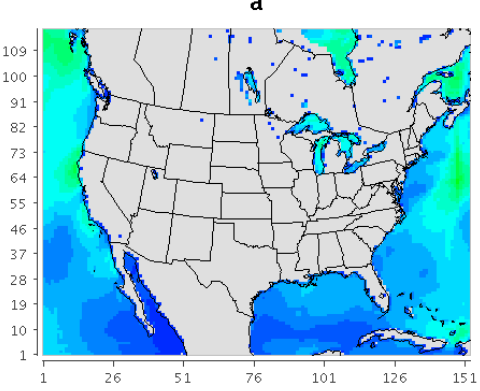

C

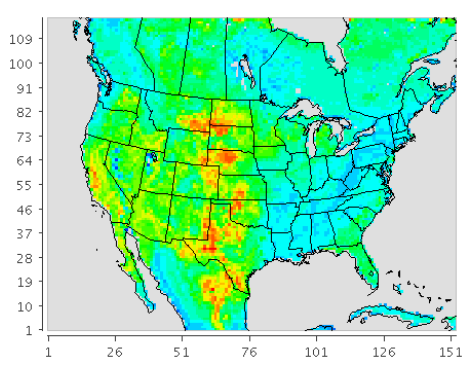

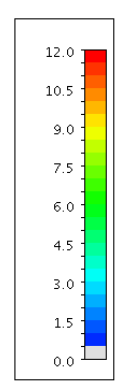
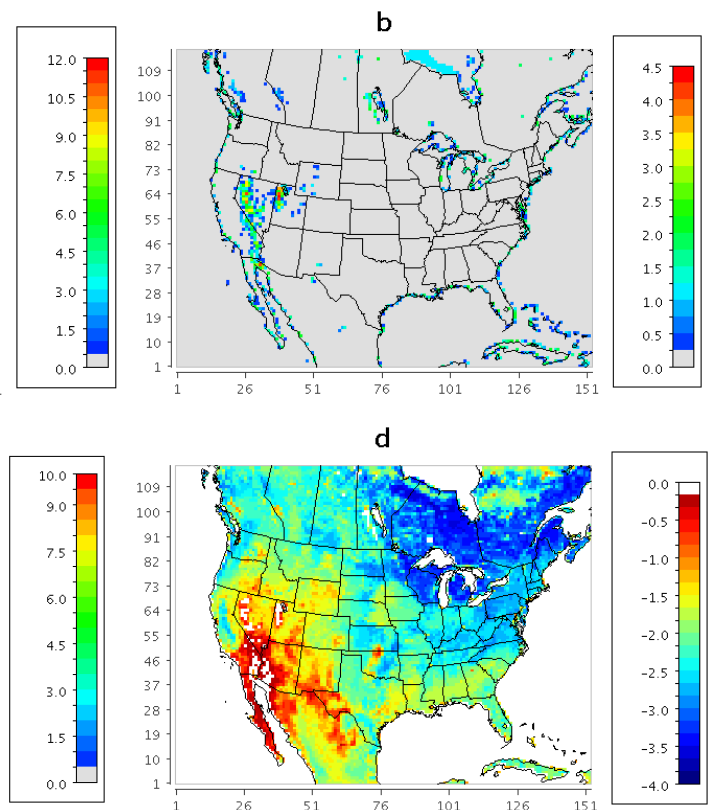

d

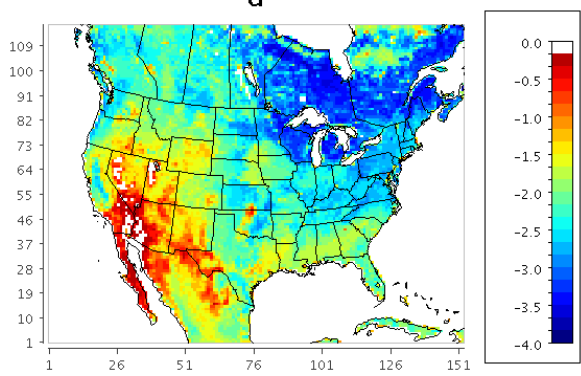

Figure 2. Monthly mean of the simulated $\mathrm{Hg}^{0}$ flux $\left(\mathrm{ng} \mathrm{m}^{-2} \mathrm{~h}^{-1}\right)$ in the summer month: (a) flux from water bodies, (b) flux from bare lands, (c) flux from soil under the canopy and (d) flux from foliage.
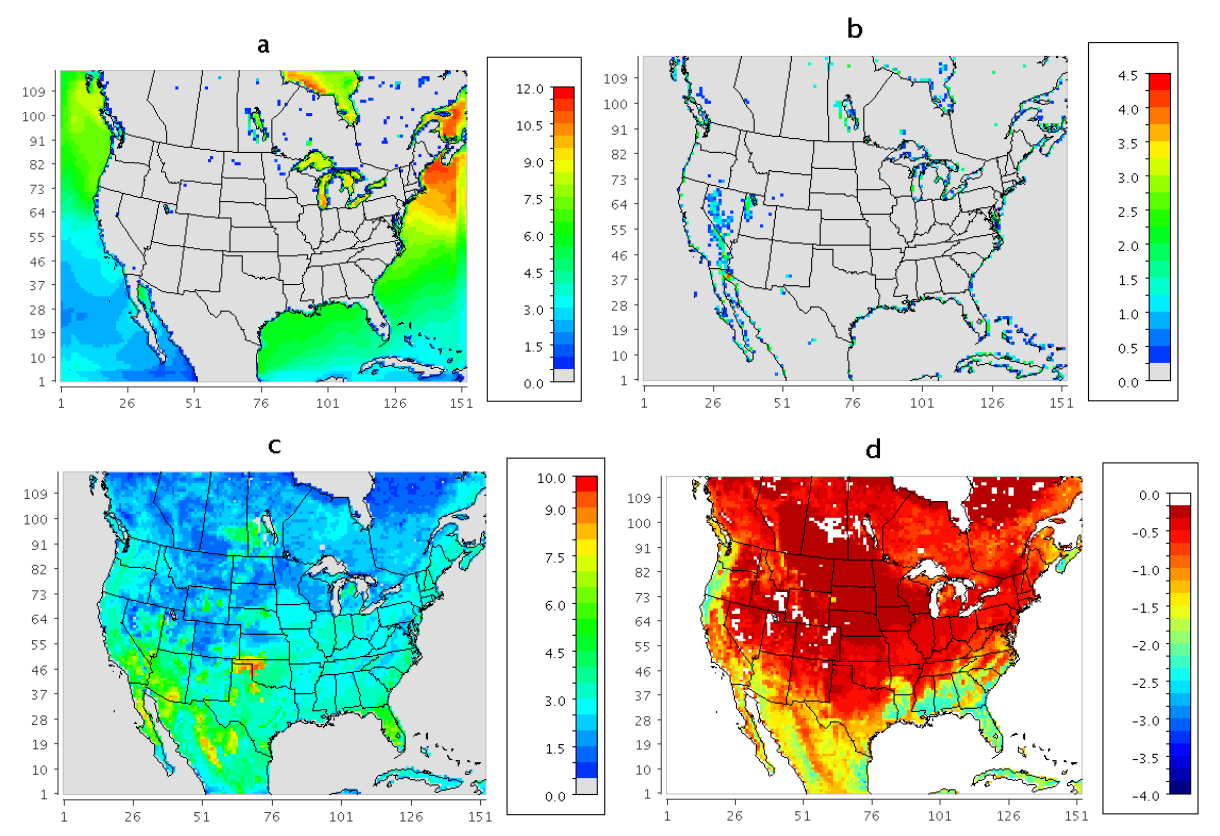

Figure 3. Monthly mean of the simulated $\mathrm{Hg}^{0}$ flux $\left(\mathrm{ng} \mathrm{m}^{-2} \mathrm{~h}^{-1}\right)$ in the winter month: (a) flux from water bodies, (b) flux from bare lands, (c) flux from soil under the canopy and (d) flux from foliage.

-2.2 and $-0.7 \mathrm{ng} \mathrm{m}^{-2} \mathrm{~h}^{-1}$ in the summer and winter month (Figs. 2d, 3d). The magnitude is similar to those measured by Ericksen et al. (2003) (a mean flux of $-3.3 \mathrm{ng} \mathrm{m}^{-2} \mathrm{~h}^{-1}$ ) and Millhollen et al. (2006) $\left(-4.1\right.$ to $\left.-0.3 \mathrm{ng} \mathrm{m}^{-2} \mathrm{~h}^{-1}\right)$. In summer, the greatest vegetative uptake of $\mathrm{Hg}^{0}$ occurs in the northeastern US because of the dense vegetation coverage. In winter, the uptake becomes much weaker due to the reduced
LAI, particularly in the north (Smith-Downey et al., 2010). The simulated deposition flux is highly correlated with LAI ( $r=0.71$ and 0.88 in winter and summer), while the correlations with friction velocity, GEM, air temperature and solar radiation are comparatively weaker. The diurnal variation for foliar flux is shown in Fig. 4c. Higher deposition occurs during daytime due to the higher air temperature and solar 

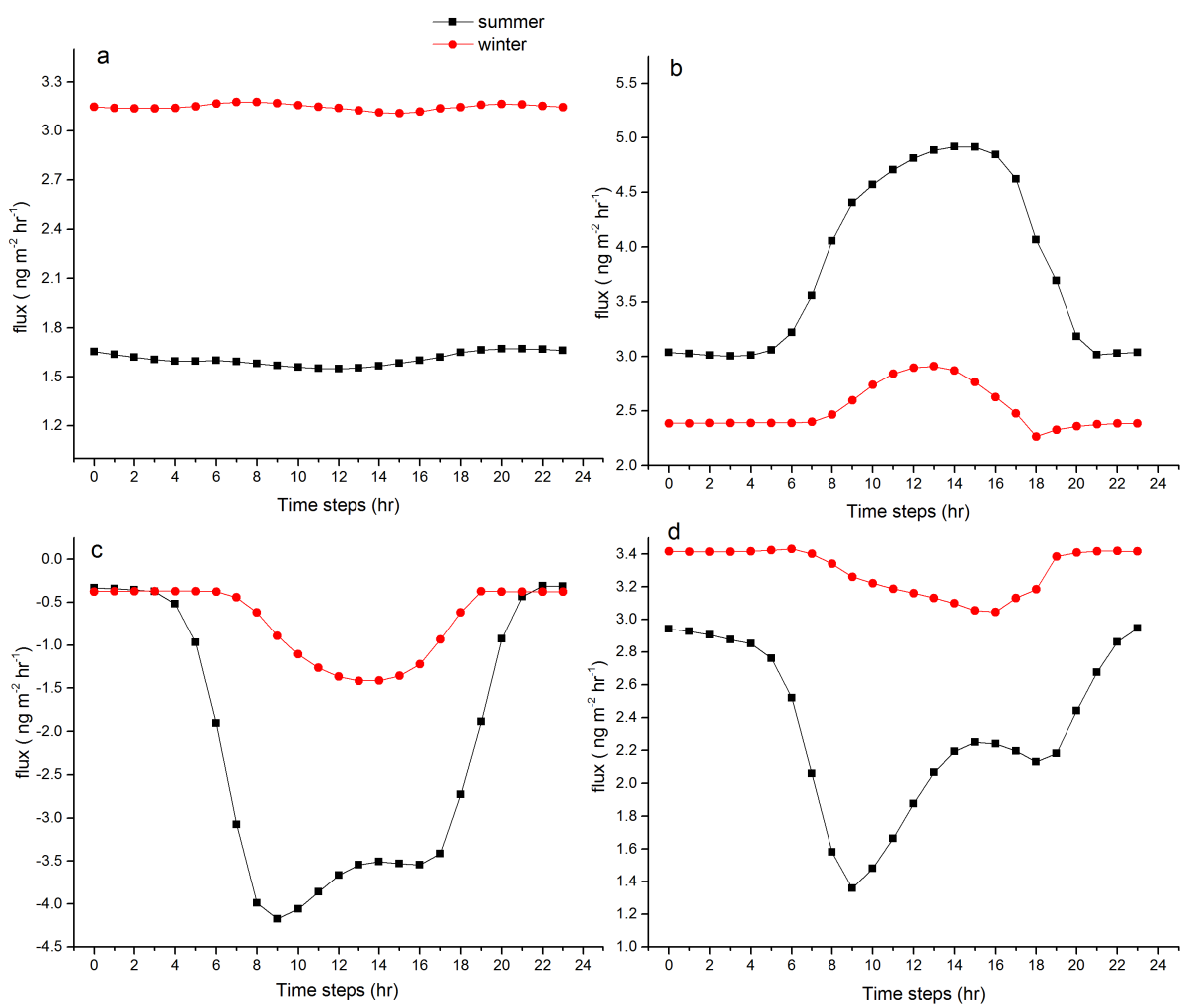

Figure 4. Diurnal variation of mean simulated $\mathrm{Hg}^{0}$ for the entire model domain (07:00 local time): (a) flux from water bodies, (b) total flux from soils (soil under the canopy and bare lands), (c) flux from foliage and (d) flux for the total domain.

irradiance (Rutter et al., 2011). The overall diurnal variation in the model domain exhibits the feature of air-foliage exchange (Fig. 4d).

The simulated flux from soil under canopy and foliar surfaces is highly dependent on the resistance terms. Presently, the values of cuticular $\left(R_{\mathrm{c}}\right)$, stomatal $\left(R_{\mathrm{g}}\right)$ and soil $\left(R_{\mathrm{S}}\right)$ resistances of $\mathrm{Hg}$ are not well understood (Holmes et al., 2011) and have been estimated by relating to the measured resistance of $\mathrm{O}_{3}, \mathrm{SO}_{2}$ and $\mathrm{H}_{2} \mathrm{O}$ (Bash, 2010; Scholtz et al., 2003; Zhang et al., 2003). There have been experimental efforts to determine $R_{\mathrm{c}}$ and $R_{\mathrm{S}}$ based on Fick's law by introducing isotopic $\mathrm{Hg}$ tracer to plants grown in an environmentally controlled chamber (Rutter et al., 2011). The resistances were found to depend on temperature, solar irradiance and $\mathrm{Hg}$ species, with reported $R_{\mathrm{c}}$ and $R_{\mathrm{S}}$ ranging from 150 to $50000 \mathrm{~m} \mathrm{~s}^{-1}$ at $0-35^{\circ} \mathrm{C}$ and $0-170 \mathrm{~W} \mathrm{~m}^{-2}$ (Millhollen et al., 2006; Rutter et al., 2011). The simulated flux in the base case applied similar resistance values in the model. However, the lack of deterministic relationships between the resistance terms and environmental parameters still represents an uncertainty and there is a need to better quantify the resistance for $\mathrm{Hg}^{0}$.

\subsection{Sensitivities analysis}

\subsubsection{Sensitivity of exchanges over water bodies}

Figure 5 shows the change of air-water flux due to the change of model variables from the low to the high experimental level (Table 2). Individually, wind speed is the most significant parameter $(p=0.003)$, followed by DGM $(p=0.004)$ and surface temperature $(p=0.059)$. On average, increasing wind speed from 0.001 to $20 \mathrm{~m} \mathrm{~s}^{-1}$ enhanced the flux by $7.6 \mathrm{ng} \mathrm{m}^{-2} \mathrm{~h}^{-1}$ ( $p=0.003$ ); increasing the DGM from 15 to $240 \mathrm{ng} \mathrm{m}^{-3}$ increases the flux by $7.0 \mathrm{ng} \mathrm{m}^{-2} \mathrm{~h}^{-1}$ $(p=0.004)$. A higher air $\mathrm{Hg}^{0}$ concentration slightly decreases the evasion flux. There is a significant synergistic effect caused by wind speed and DGM concentration $(p=0.004)$. Increasing both variables simultaneously from the low to high level (Table 2 ) causes an additional $48 \%$ increase in the evasion flux. The wind speed and surface temperature also have a synergistic effect, although not as significant ( $p=0.059)$, followed by the effect enhanced by DGM concentration and surface temperature $(p=0.076)$. The effects of higher DGM concentration and air $\mathrm{Hg}^{0}$ concentration offset each other, leading to a nearly zero effect on flux $(p=1.000)$.

In the base case, a uniform DGM concentration was assumed. The spatially constant DGM level represents a 


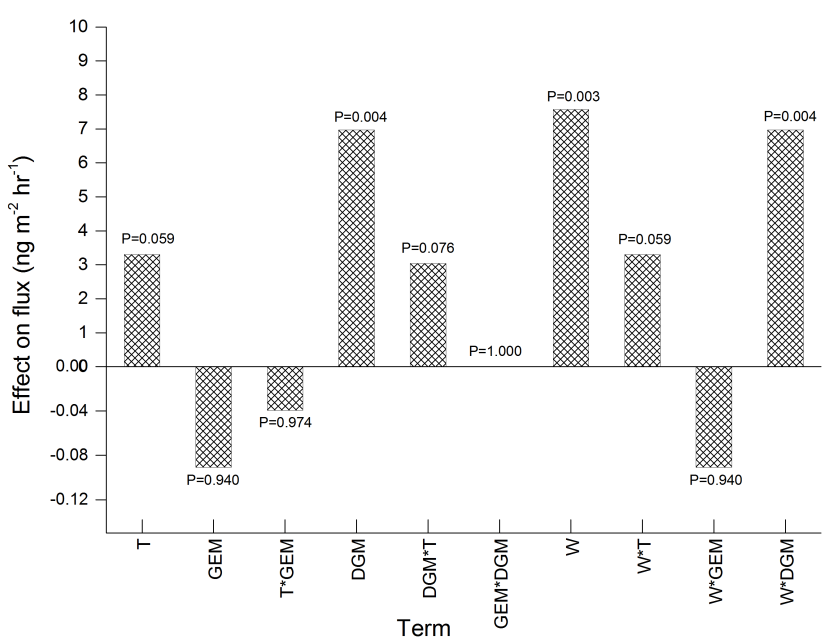

Figure 5. Sensitivity analysis based on the $2^{4}$ factorial design shown in Table 2 (water bodies). $T$ denotes air temperature at water surface, GEM denotes air Hg concentration, DGM denotes dissolved gaseous $\mathrm{Hg}$ concentration in surface water, $W$ denotes wind speed, and "**” denotes the interaction effects.

significant uncertainty since other environmental parameters such as temperature, wind speed can be estimated reliably through meteorological simulations at a high spatial resolution. The mechanism leading to the net DGM formation in surface water is complex and not fully understood (Qureshi et al., 2010). It has been suggested that dissolved organic matter (Amyot et al., 1994, 1997), hydroxyl radicals (Zhang and Lindberg, 2001) and oxyhalide radicals (e.g., $\mathrm{OCl}^{-}, \mathrm{OBr}^{-}$) (Lalonde et al., 2001) can participate in the sunlight-induced processes that produce DGM. Data on measured net DGM concentration over vast water bodies are not readily available because of a limited number of cruise campaigns (Mason et al., 1998, 2001b; Andersson et al., 2011). Strode et al. (2007) and Soerensen et al. (2010) estimated the global distribution of DGM in sea water and showed that accurate representation of DGM concentration is key for calculating air-water exchange. More knowledge on the temporal and spatial distribution of net DGM concentration in surface water can greatly reduce the model uncertainty. Experimental investigation to better understand the chemical pathways leading to net DGM formation will also help constrain the model estimate.

\subsubsection{Sensitivity of exchange over bare lands}

Figure 6 illustrates the model response to the model variables over bare lands (Table 3). Soil $\mathrm{Hg}$ content, friction velocity, air temperature and the scaling factor $\beta_{\mathrm{Hg}^{0}}$ (Eq. 7) have a positive effect on the simulated $\mathrm{Hg}$ flux, while the soil organic content has a negative effect. On average, increasing soil $\mathrm{Hg}$ content from 50 to $1000 \mathrm{ng} \mathrm{g}^{-1}$ soil enhances the flux by $55.3 \mathrm{ng} \mathrm{m}^{-2} \mathrm{~h}^{-1}(p=0.013)$; increasing friction velocity from 0.0001 to $1 \mathrm{~m} \mathrm{~s}^{-1}$ increases the flux by

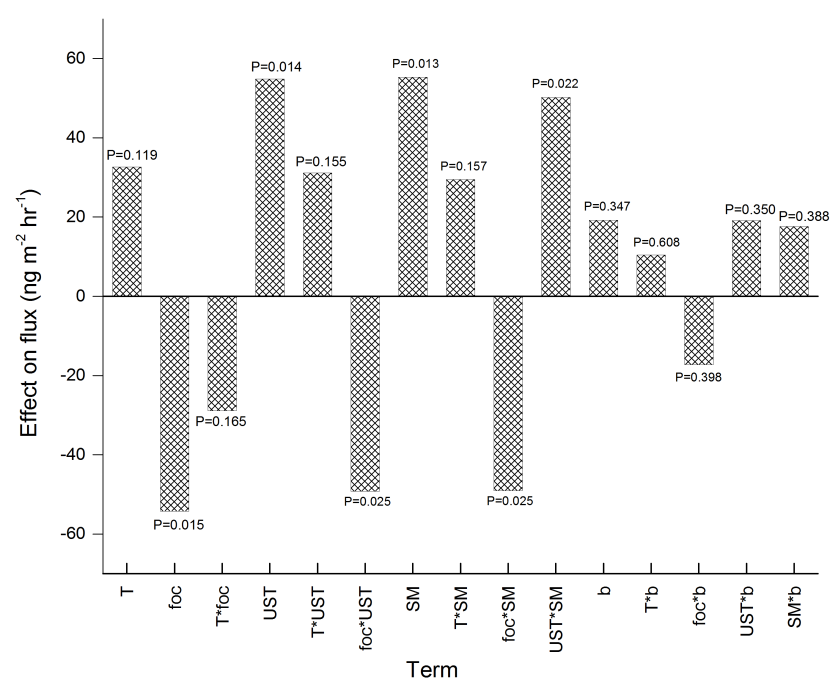

Figure 6. Sensitivity analysis based on the $2^{5}$ factorial design for bare lands after prescreening model variables shown in Table 3 to isolate the significant factors. $T$ denotes surface air temperature, foc denotes fraction of organic carbon in soil, UST denotes friction velocity, SM denotes soil mercury content, $b$ denotes scaling factor for $\mathrm{Hg}$ reactivity $\left(\beta_{\mathrm{Hg}^{0}}\right)$, and “*” denotes interaction effects.

$54.8 \mathrm{ng} \mathrm{m}^{-2} \mathrm{~h}^{-1}(p=0.014)$. On the other hand, increasing the soil organic content from 0.6 to $10 \%$ reduces the flux by $54.2 \mathrm{ng} \mathrm{m}^{-2} \mathrm{~h}^{-1}(p=0.015)$. There are several notable interactions among the model variables. First, the positive effects of soil $\mathrm{Hg}$ content and friction velocity can be completely offset by soil organic content (Fig. 6). An increase in soil organic content substantially decreases the soil Hg compensation point (Eq. 6), suggesting the significant role of soil organic matter in preventing $\mathrm{Hg}$ from evading $(p=0.025)$. There is a strong synergistic effect between friction velocity and soil $\mathrm{Hg}$ content $(p=0.022)$, leading to an additional $46 \%$ increase compared to the sum of the two individual effects (Fig. 6). Quasi-laminar layer resistance $\left(R_{\mathrm{b}}\right)$ and aerodynamic resistance $\left(R_{\mathrm{a}}\right)$ both decrease with increasing friction velocity. Coupled with the increased soil $\mathrm{Hg}$ compensation point at higher soil $\mathrm{Hg}$ content (Eq. 6), the flux is greatly enhanced (Fig. 6). Overall, friction velocity, soil $\mathrm{Hg}$ and organic content are the most influential parameters for $\mathrm{Hg}$ exchanges over bare lands. Other parameters including temperature, $\mathrm{Hg}$ scaling factor ( $\beta_{\mathrm{Hg}}$ in Eq. 7) and other interaction terms have less significant effects.

\subsubsection{Sensitivity of exchange over canopy}

Figure 7 illustrates the sensitivity of simulated $\mathrm{Hg}$ flux over canopy to the model variables (Table 4). For comparison, the sensitivity results for air-soil exchange under canopy are also shown. The forcing of air-canopy exchange is dominated by the air-soil exchange under canopy at the two experimental levels. This resembles the $\mathrm{Hg}^{0}$ emission characteristics 
Table 3. Examined model variables and the experimental levels of factorial design for air-soil exchange over sparsely vegetated land, bare ground tundra and snow/ice surfaces.

\begin{tabular}{|c|c|c|c|}
\hline Term & Description & Low level & High level \\
\hline$T$ & Air temperature at $2 \mathrm{~m}\left({ }^{\circ} \mathrm{C}\right)$ & -2 & 40 \\
\hline Q2 & Water vapor mixing ratio $\left(\mathrm{Kg} \mathrm{Kg}^{-1}\right)$ & $0.0005^{\mathrm{a}}$ & $0.05^{\mathrm{a}}$ \\
\hline$f_{\mathrm{Oc}}$ & Fraction of organic carbon in surface soil & $0.006^{\mathrm{b}}$ & $0.1^{\mathrm{c}}$ \\
\hline UST & Friction velocity $\left(\mathrm{m} \mathrm{s}^{-1}\right)$ & $0.0001^{\mathrm{d}}$ & $1.0^{\mathrm{d}}$ \\
\hline SM & Soil $\mathrm{Hg}$ content $\left(\mathrm{ng} \mathrm{g}^{-1}\right.$ soil) & $50^{\mathrm{e}}$ & $1000^{\mathrm{e}}$ \\
\hline GEM & Air $\mathrm{Hg}^{0}$ concentration $\left(\mathrm{ng} \mathrm{m}^{-3}\right)$ & 1.0 & 2.0 \\
\hline SNOWH & Snow depth $(\mathrm{m})$ & $0^{f}$ & $0.4999^{f}$ \\
\hline$\beta_{\mathrm{Hg}^{0}}$ & Scaling factor of reactivity $\mathrm{Hg}$ & $0.1^{\mathrm{g}}$ & $0.2^{\mathrm{h}}$ \\
\hline DC & Dew condition & $\mathrm{No}^{\mathrm{i}}$ & Yes $^{\mathrm{i}}$ \\
\hline $\mathrm{RC}$ & Rain condition & $\mathrm{No}^{\mathrm{j}}$ & Yes $^{\mathrm{j}}$ \\
\hline MC & Moist soil condition & $\mathrm{No}^{\mathrm{k}}$ & $\mathrm{Yes}^{\mathrm{k}}$ \\
\hline
\end{tabular}

${ }^{\text {a }}$ Kwun and You (2009); ${ }^{\text {b }}$ suggested default value for modeling of volatilized contaminant to air by USEPA (2004); ${ }^{\mathrm{c}}$ upper limit of the forest soils (Jones et al., 2004); ${ }^{\mathrm{d}}$ Akkarappuram and Raman (1988) e Carpi and Lindberg (1998); ${ }^{\mathrm{f}}$ has effect on ground and cuticular resistance, Zhang et al. (2003); ${ }^{\mathrm{g}}$ Zhang et al. (2012); ${ }^{\mathrm{h}}$ Zhang et al. (2009a); ${ }^{\mathrm{i}}$ air temperature below dew point represents low level and higher than dew point represents high level (Zhang et al., 2003); ${ }^{j}$ presence of precipitation events has effects on ground and cuticular resistance terms (Zhang et al., 2003); ${ }^{\mathrm{k}}$ soil moisture $\leq 20 \%$ represents low level, and $>20 \%$ represents high level (Zotarelli et al., 2010).

Table 4. Examined model variables and the experimental levels of factorial design for air-canopy exchange.

\begin{tabular}{|c|c|c|c|}
\hline Term & Description & Low level & High level \\
\hline$T$ & Air temperature at $2 \mathrm{~m}\left({ }^{\circ} \mathrm{C}\right)$ & -2 & 40 \\
\hline$f_{\mathrm{oc}}$ & Fraction of organic carbon in surface soil & 0.006 & 0.1 \\
\hline UST & Friction velocity $\left(\mathrm{m} \mathrm{s}^{-1}\right)$ & 0.0001 & 1.0 \\
\hline SM & Soil total $\mathrm{Hg}$ content $\left(\mathrm{ng} \mathrm{m}^{-3}\right)$ & 50 & 1000 \\
\hline$\beta_{\mathrm{Hg}^{0}}$ & Scaling factor of reactivity $\mathrm{Hg}$ & 0.1 & 0.2 \\
\hline SNOWH & Snow depth $(\mathrm{m})$ & 0 & 0.4999 \\
\hline LAI & Leaf area index $\left(\mathrm{m}^{2} \mathrm{~m}^{-2}\right)$ & $1.0^{\mathrm{a}}$ & $5.0^{\mathrm{a}}$ \\
\hline SR & Solar irradiation $\left(\mathrm{W} \mathrm{m}^{-2}\right)$ & 0 & 1000 \\
\hline Leaf_Hg & $\mathrm{Hg}$ concentration in leaf rinse ( $\mathrm{ng} \mathrm{m}^{-2}$ leaf) & $0.02^{\mathrm{b}}$ & $2.10^{\mathrm{c}}$ \\
\hline Stomata_Hg & $\mathrm{Hg}$ previously deposited to leaf stomata ( $\mathrm{ng} \mathrm{m}^{-2}$ leaf) & $0.13^{\mathrm{d}}$ & $0.59^{\mathrm{d}}$ \\
\hline GEM & Air $\mathrm{Hg}^{0}$ concentration $\left(\mathrm{ng} \mathrm{m}^{-3}\right)$ & 1.0 & 2.0 \\
\hline LAP & Leaf-air partitioning coefficient $\left(\mathrm{m}^{3}\right.$ air $\mathrm{m}^{-3}$ leaf) & $30000^{\mathrm{e}}$ & $6000000^{\mathrm{e}}$ \\
\hline DC & Dew condition & No & Yes \\
\hline $\mathrm{RC}$ & Rain condition & No & Yes \\
\hline MC & Moist soil condition & No & Yes \\
\hline
\end{tabular}

${ }^{a}$ Gower et al. (1999); ${ }^{\mathrm{b}}$ Frescholtz et al. (2003); ${ }^{\mathrm{c}}$ Fay and Gustin (2007); ${ }^{\mathrm{d}}$ Poissant et al. (2008); ${ }^{\mathrm{e}}$ Rutter et al. (2011).

observed in a gas exchange system, which suggested that the evasion from soils is much greater than the emission from the plants grown in the chamber (Frescholtz and Gustin, 2004; Frescholtz et al., 2003). After the factor prescreening step (Figs. S2-S7 in the Supplement), the simulated flux is particularly sensitive to five parameters. Friction velocity (positive effect, $p=0.020$ ), soil $\mathrm{Hg}$ content (positive effect, $p=0.028$ ) and soil organic content (negative effect, $p=0.030$ ) are the most significant model parameters (Fig. 7). These effects are similar to the sensitivity results of air-soil exchange over bare lands (Figs. 6 and 7) but slightly weaker based on the $p$ values because of the "shielding" of vegetation coverage that modifies the values of the resistance terms ( $R_{\mathrm{b}}$ and $R_{\mathrm{ac}}$ ) (Zhang et al., 2002a). Highly moist soil (soil moisture content $>20 \%$, Table 4 ) has a negative effect because it effectively increases soil diffusion resistance $\left(R_{\mathrm{g}}\right)$ (Zhang et al., 2003), although the effect is less significant $(p=0.289)$. Air temperature also has a positive effect, as anticipated $(p=0.180)$. The synergistic effect caused by friction velocity and soil $\mathrm{Hg}$ content is significant for the aircanopy exchange ( $p=0.028$, Fig. 7), enhancing the evasion flux by $47 \%\left(77.8 \mathrm{ng} \mathrm{m}^{-2} \mathrm{~h}^{-1}\right)$. Both soil organic content 


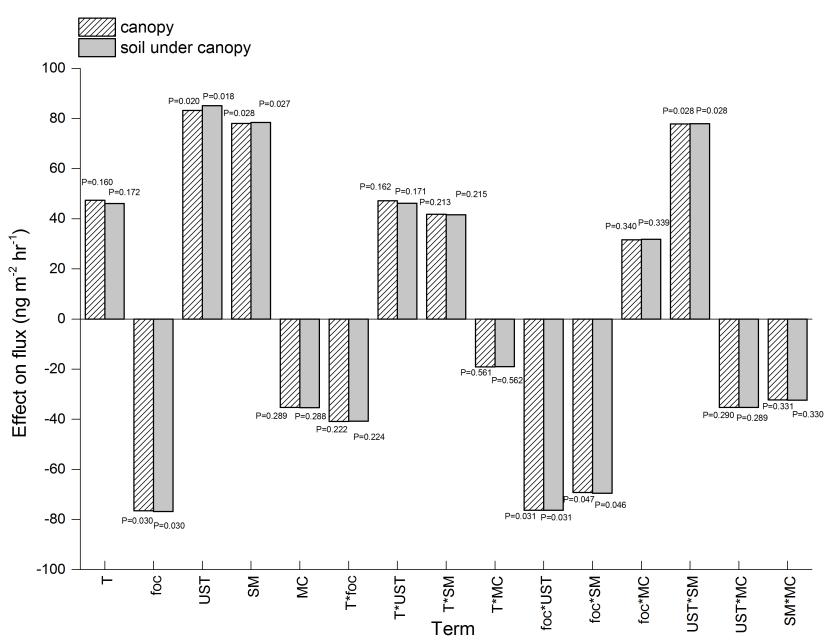

Figure 7. Sensitivity analysis based on the $2^{5}$ factorial design at canopy level after prescreening model variables shown in Table 4 to isolate the significant factors. The overall flux at canopy level is dominated by the soil flux under the canopy (the sensitivity of foliar exchange is shown in Fig. 8). $T$ denotes surface air temperature, foc denotes fraction of organic carbon in soil, UST denotes friction velocity, SM denotes soil $\mathrm{Hg}$ content, MC denotes soil moisture, and "** denotes interaction effects.

and highly moist soil condition can offset the positive effects caused by higher friction velocity, soil $\mathrm{Hg}$ content and air temperature at different degrees (Fig. 7), with the soil organic content being more influential. Higher soil organic content at high soil moisture ( $>20 \%$ ) yields a weak positive effect $(p=0.340)$, which is interpreted as the combined negative effect of the two parameters is smaller than the sum of the two individual effects. Overall, these characteristics resemble the air-soil exchange because the air-canopy exchange is dominated by the air-soil exchange under canopy.

Atmospheric mercury can deposit on the surface of cuticle or be accumulated in leaves through stomatal uptake (Fig. 1). For cuticular exchange, air temperature has a significant positive effect (Fig. 8). Since air-cuticle exchange is mainly deposition (negative flux), this means that a higher air temperature leads to smaller deposition or greater evasion $(p<0.001)$. Friction velocity has a strong negative effect (i.e., higher deposition at higher friction velocity, $p<0.001)$ on the simulated flux. Higher soil organic content $(p=0.009)$ and highly moist $(>20 \%)$ soil $(p=0.194)$ increase the simulated flux (i.e., weaken the deposition) by decreasing the canopy compensation point ( $\chi_{c}$ in Eq. 8). Under this circumstance, $\mathrm{Hg}$ deposits preferentially to soil and therefore there is a reduced deposition on cuticle. Higher soil Hg content decreases the flux ( $p=0.008)$ by increasing the overall compensation point ( $\chi_{\mathrm{cnp}}$ in Eq. 8), suggesting greater deposition on cuticle at higher soil $\mathrm{Hg}$ content. For stomatal exchange, the trend of the single-factor effect is the same as that of cuticular exchange.

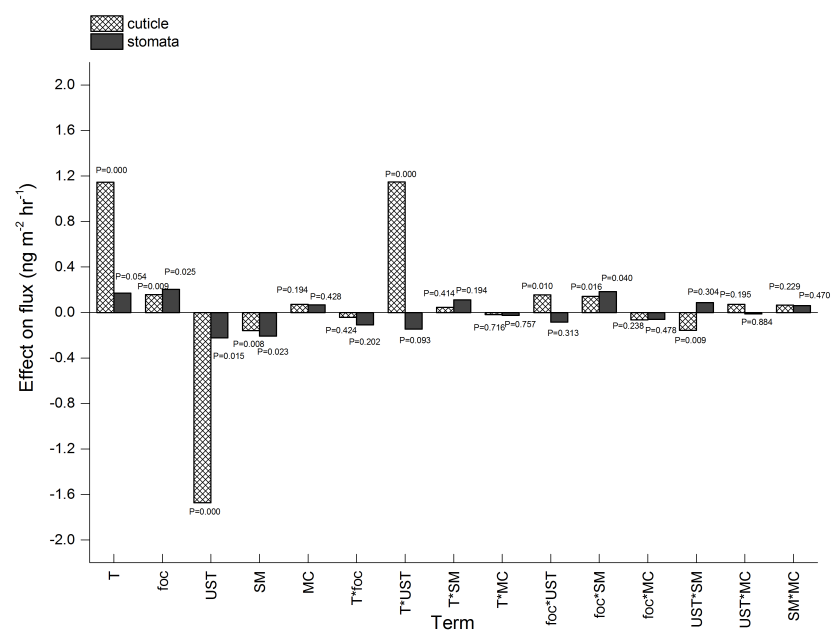

Figure 8. Sensitivity analysis based on the $2^{5}$ factorial design for foliar exchange after prescreening model variables shown in Table 4 to isolate the significant factors. $T$ denotes surface air temperature, foc denotes fraction of organic carbon in soil, UST denotes friction velocity, SM denotes soil $\mathrm{Hg}$ content, MC denotes soil moisture, and "*" denotes interaction effects.

Several notable interaction effects are observed for foliar exchanges. For cuticular exchange, the deposition is reversed from deposition to evasion at the high air temperature level, leading to the overall positive interaction effect for air temperature and friction velocity (Fig. $8, p<0.001$ ). The positive effect of soil organic content significantly offsets the negative effect of friction velocity $(p=0.010)$ and soil $\mathrm{Hg}$ content $(p=0.016)$. For stomatal exchange, the only significant interaction effect is between soil organic and $\mathrm{Hg}$ content, which is more strongly dominated by soil organic content. Overall, the foliar exchange is primarily controlled by air temperature and friction velocity because the resistance terms can be affected by the two variables. This is in contrast to the evapotranspiration approach where soil $\mathrm{Hg}$ content plays a predominant role in simulated $\mathrm{Hg}^{0}$ evasion flux (Bash et al., 2004; Gbor et al., 2006).

In this analysis, the effect of solar irradiance is not as significant as the selected parameters under the resistance model scheme and has been ruled out during the prescreening for the model variables (Sect. 2.4 and Figs. S2-S6). In the model, solar irradiation can influence the flux in three ways: (1) through modifying the rate constant of $\mathrm{Hg}$ (II) reduction in soils and foliage (Eqs. 6, 10 and 16), (2) through forcing the change of aerodynamic resistance $\left(R_{\mathrm{a}}\right.$ and $\left.R_{\mathrm{ac}}\right)$ and (3) through forcing the change of cuticular and stomatal resistance terms ( $R_{\mathrm{c}}$ and $\left.R_{\mathrm{st}}\right)$. For air-soil exchange, the effect of solar irradiance on the reduction rate constant is the most sensitive process (Eqs. 6 and 10). The photoreduction of $\mathrm{Hg}(\mathrm{II})$ in soils has been suggested to be responsible for the increased soil flux observed under sunlit condition (Gustin et al., 2002). There have been kinetic studies showing that 
increasing UV-A intensity by $75 \%$ approximately doubles the photoreduction rate in the aqueous phase (Qureshi et al., 2010). However, the effect of lights on the kinetics of $\mathrm{Hg}$ (II) reduction in soils is poorly understood. In this modeling, the photoreduction rate constant was set to a mean value (Eq. 6). This limits a full examination of the true impact of solar irradiation on the simulated Hg flux. Results from experimental studies on $\mathrm{Hg}$ (II) photoreduction rates will help reduce this model uncertainty. For foliar exchange, solar irradiation has a weak positive effect on the flux (i.e., slightly weakens deposition, Supplement Fig. S4) but has a significant positive effect on the stomatal exchange ( $p=0.004$, Supplement Fig. S5).

\section{Conclusions}

An updated model for estimating the bidirectional airsurface exchange of $\mathrm{Hg}$ is presented based on the current understanding of surface resistance schemes. From the basecase results, water and soil surfaces are net sources and vegetation is a net sink of $\mathrm{Hg}^{0}$. Each natural surface exhibits a different diurnal and seasonal variation. Sensitivity analysis of model variables using a two-level factorial design of experiments shows that atmospheric shear flows (surface wind over water and friction velocity of terrestrial surfaces), dissolved gaseous mercury (DGM) concentration, soil organic and $\mathrm{Hg}$ content, and air temperature are the most influential factors controlling the magnitude of the atmosphere-biosphere exchange of $\mathrm{Hg}^{0}$. However, the positive effect of friction velocity and soil $\mathrm{Hg}$ content on the evasion flux from soil and canopy can be greatly offset by the negative effect of soil organic content. Significant synergistic effects are identified between surface wind and DGM level for water surface, and between soil $\mathrm{Hg}$ content and friction velocity for soil surface, leading to $\sim 50 \%$ enhanced flux in the combined effect compared to the sum of their individual effects. The airfoliage exchange is mainly controlled by surface resistance terms controlled by environmental parameters such as solar irradiation and air temperature.

The uncertainty in this modeling assessment is primarily from the lack of knowledge in (1) the spatial distribution of organic and $\mathrm{Hg}$ content in soil and DGM concentration in water, (2) the reduction mechanism and kinetics of $\mathrm{Hg}$ (II) in soil and water and (3) the values of resistance terms over different natural surfaces. More research in providing geospatial distribution of $\mathrm{Hg}$ in water and soil will greatly improve the model estimate. Further elucidation on the interaction of $\mathrm{Hg}$ and organic carbon in top soil and surface water, as well as quantification of the surface resistance terms specific to $\mathrm{Hg}$ species, will also help improve the model scheme. Recent field and experimental investigations have suggested that organic carbon in soil potentially shapes the distribution of $\mathrm{Hg}$ in forest at continental scales (Obrist et al., 2011) and that the long-term $\mathrm{Hg}$ evasion from soil is highly related to the $\mathrm{Hg}$ and organic carbon interactions (Smith-Downey et al., 2010).
Given the predominance of soil organic content in reducing soil $\mathrm{Hg}$ evasion flux using the mechanistic approach in this study, soil organic content is likely the controlling factor determining the intensity of air-soil $\mathrm{Hg}^{0}$ exchange.

\section{The Supplement related to this article is available online at doi:10.5194/acp-14-6273-2014-supplement.}

Acknowledgements. This work was funded by the National "973" Program of China (2013CB430003); the National Science Foundation of China (41030752); the National Institute of Food and Agriculture, US Department of Agriculture (2009-38899-20017); and the State Key Laboratory of Environmental Geochemistry, IGCAS. The funding support is gratefully acknowledged. We thank P. Pongprueksa for providing $\mathrm{Hg}$ concentration data for this work and P. Singhasuk for creating the visualization in Fig. 1.

Edited by: A. Dastoor

\section{References}

Akkarappuram, A. F. and Raman, S.: A comparison of surface friction velocities estimated by dissipation and iterative bulk aerodynamic methods during gale, Geophys. Res. Lett., 15, 401-404, doi:10.1029/GL015i005p00401, 1988.

Amyot, M., Mierle, G., Lean, D. R. S., and Mcqueen, D. J.: Sunlight-Induced Formation of Dissolved Gaseous Mercury in Lake Waters, Environ. Sci. Technol., 28, 2366-2371, doi:10.1021/Es00062a022, 1994.

Amyot, M., Gill, G. A., and Morel, F. M. M.: Production and loss of dissolved gaseous mercury in coastal seawater, Environ. Sci. Technol., 31, 3606-3611, doi:10.1021/Es9703685, 1997.

Andersson, M. E., Gardfeldt, K., Wangberg, I., and Stromberg, D.: Determination of Henry's law constant for elemental mercury, Chemosphere, 73, 587-592, doi:10.1016/j.chemosphere.2008.05.067, 2008.

Andersson, M. E., Sommar, J., Gardfeldt, K., and Jutterstrom, S.: Air-sea exchange of volatile mercury in the North Atlantic Ocean, Mar. Chem., 125, 1-7, doi:10.1016/j.marchem.2011.01.005, 2011.

Bash, J. O.: Description and initial simulation of a dynamic bidirectional air-surface exchange model for mercury in Community Multiscale Air Quality (CMAQ) model, J. Geophys. Res.Atmos., 115, D06305, doi:10.1029/2009jd012834, 2010.

Bash, J. O., Miller, D. R., Meyer, T. H., and Bresnahan, P. A.: Northeast United States and Southeast Canada natural mercury emissions estimated with a surface emission model, Atmos. Environ., 38, 5683-5692, doi:10.1016/j.atmosenv.2004.05.058, 2004.

Bash, J. O., Bresnahan, P., and Miller, D. R.: Dynamic surface interface exchanges of mercury: A review and compartmentalized modeling framework, J. Appl. Meteorol. Clim., 46, 1606-1618, doi:10.1175/jam2553.1, 2007.

Calhoun, F. G., Smeck, N. E., Slater, B. L., Bigham, J. M., and Hall, G. F.: Predicting bulk density of Ohio soils from morphology, 
genetic principles, and laboratory characterization data, Soil Sci. Soc. Am. J., 65, 811-819, 2001.

Capiomont, A., Piazzi, L., and Pergent, G.: Seasonal variations of total mercury in foliar tissues of Posidonia oceanica, J. Mar. Biol. Assoc. UK, 80, 1119-1123, doi:10.1017/S0025315400003192, 2000.

Carpi, A. and Lindberg, S. E.: Application of a Teflon (TM) dynamic flux chamber for quantifying soil mercury flux: Tests and results over background soil, Atmos. Environ., 32, 873-882, doi:10.1016/S1352-2310(97)00133-7, 1998.

Cui, L. W., Feng, X. B., Lin, C. J., Wang, X. M., Meng, B., Wang, X., and Wang, H.: Accumulation and translocation of ${ }^{198} \mathrm{Hg}$ in four crop species, Environ. Toxicol. Chem., 33, 334-340, doi:10.1002/etc.2443, 2014.

Ericksen, J. A., Gustin, M. S., Schorran, D. E., Johnson, D. W., Lindberg, S. E., and Coleman, J. S.: Accumulation of atmospheric mercury in forest foliage, Atmos. Environ., 37, 16131622, doi:10.1016/s1352-2310(03)00008-6, 2003.

Ericksen, J. A., Gustin, M. S., Xin, M., Weisberg, P. J., and Fernandez, G. C. J.: Air-soil exchange of mercury from background soils in the United States, Sci. Total Environ., 366, doi:10.1016/j.scitotenv.2005.08.019, 2006.

Fay, L. and Gustin, M.: Assessing the influence of different atmospheric and soil mercury concentrations on foliar mercury concentrations in a controlled environment, Water Air Soil Pollut., 181, 373-384, doi:10.1007/s11270-006-9308-6, 2007.

Frescholtz, T. F., Gustin, M. S., Schorran, D. E., and Fernandez, G. C. J.: Assessing the source of mercury in foliar tissue of quaking aspen, Environ. Toxicol. Chem., 22, 2114-2119, doi:10.1897/1551-5028(2003)022<2114:Atsomi > 2.0.Co;2, 2003.

Frescholtz, T. F. and Gustin, M. S.: Soil and foliar mercury emission as a function of soil concentration, Water Air Soil Pollut., 155, 223-237, doi:10.1023/B:Wate.0000026530.85954.3f, 2004.

Friedli, H. R., Arellano, A. F., Cinnirella, S., and Pirrone, N.: Initial Estimates of Mercury Emissions to the Atmosphere from Global Biomass Burning, Environ. Sci. Technol., 43, 3507-3513, doi:10.1021/Es802703g, 2009.

Gabriel, M. C., Williamson, D. G., Zhang, H., Brooks, S., and Lindberg, S.: Diurnal and seasonal trends in total gaseous mercury flux from three urban ground surfaces, Atmos. Environ., 40, 4269-4284, doi:10.1016/j.atmosenv.2006.04.004, 2006.

Gbor, P. K., Wen, D. Y., Meng, F., Yang, F. Q., Zhang, B. N., and Sloan, J. J.: Improved model for mercury emission, transport and deposition, Atmos. Environ., 40, 973-983, doi:10.1016/j.atmosenv.2005.10.040, 2006.

Gower, S. T., Kucharik, C. J., and Norman, J. M.: Direct and indirect estimation of leaf area index, $\mathrm{f}(\mathrm{APAR})$, and net primary production of terrestrial ecosystems, Remote Sens. Environ., 70, 29-51, doi:10.1016/S0034-4257(99)00056-5, 1999.

Graydon, J. A., St Louis, V. L., Hintelmann, H., Lindberg, S. E., Sandilands, K. A., Rudd, J. W. M., Kelly, C. A., Tate, M. T., Krabbenhoft, D. P., and Lehnherr, I.: Investigation of Uptake and Retention of Atmospheric $\mathrm{Hg}$ (II) by Boreal Forest Plants Using Stable Hg Isotopes, Environ. Sci. Technol., 43, 4960-4966, doi:10.1021/es900357s, 2009.

Guo, Y. Y., Amundson, R., Gong, P., and Yu, Q.: Quantity and spatial variability of soil carbon in the conterminous United States,
Soil Sci. Soc. Am. J., 70, 590-600, doi:10.2136/sssaj2005.0162, 2006.

Gustin, M. S., Biester, H., and Kim, C. S.: Investigation of the light-enhanced emission of mercury from naturally enriched substrates, Atmos. Environ., 36, 3241-3254, doi:10.1016/S13522310(02)00329-1, 2002.

Gustin, M. S., Lindberg, S. E., and Weisberg, P. J.: An update on the natural sources and sinks of atmospheric mercury, Appl. Geochem., 23, 482-493, doi:10.1016/j.apgeochem.2007.12.010, 2008.

Hartman, J. S., Weisberg, P. J., Pillai, R., Ericksen, J. A., Kuiken, T., Lindberg, S. E., Zhang, H., Rytuba, J. J., and Gustin, M. S.: Application of a Rule-Based Model to Estimate Mercury Exchange for Three Background Biomes in the Continental United States, Environ. Sci. Technol., 43, 4989-4994, doi:10.1021/es900075q, 2009.

Holmes, H. A., Pardyjak, E. R., Perry, K. D., and Abbott, M. L.: Gaseous dry deposition of atmospheric mercury: A comparison of two surface resistance models for deposition to semiarid vegetation, J. Geophys. Res.-Atmos., 116, D14306, doi:10.1029/2010jd015182, 2011.

Jones, R. J. S., Rusco, R. H. E., Loveland, P. J., and Montanarella, L.: The map of organic carbon in topsoils in Europe: Explanation of Special Publication Ispra 2004, No.72, (S.P.I.04.72)17, EUR 21209 EN, 2004.

Kuiken, T., Gustin, M., Zhang, H., Lindberg, S., and Sedinger, B.: Mercury emission from terrestrial background surfaces in the eastern USA. II: Air/surface exchange of mercury within forests from South Carolina to New England, Appl. Geochem., 23, 356368, doi:10.1016/j.apgeochem.2007.12.007, 2008a.

Kuiken, T., Zhang, H., Gustin, M., and Lindberg, S.: Mercury emission from terrestrial background surfaces in the eastern USA. Part I: Air/surface exchange of mercury within a southeastern deciduous forest (Tennessee) over one year, Appl. Geochem., 23, 345-355, doi:10.1016/j.apgeochem.2007.12.006, 2008b.

Kwun, J. H. and You, S. H.: Numerical Study of Sea Winds Simulated by the High-Resolution Weather Research and Forecasting (WRF) Model, Asia-Pac J. Atmos. Sci., 45, 523-554, 2009.

Lalonde, J. D., Amyot, M., Kraepiel, A. M. L., and Morel, F. M. M.: Photooxidation of $\mathrm{Hg}(0)$ in artificial and natural waters, Environ. Sci. Technol., 35, 1367-1372, doi:10.1021/Es001408z, 2001.

Lin, C. J., Lindberg, S. E., Ho, T. C., and Jang, C.: Development of a processor in BEIS3 for estimating vegetative mercury emission in the continental United States, Atmos. Environ., 39, 7529_ 7540, doi:10.1016/j.atmosenv.2005.04.044, 2005.

Lin, C. J., Pongprueksa, P., Lindberg, S. E., Pehkonen, S. O., Byun, D., and Jang, C.: Scientific uncertainties in atmospheric mercury models I: Model science evaluation, Atmos. Environ., 40, 2911 2928, doi:10.1016/j.atmosenv.2006.01.009, 2006.

Lin, X. and Tao, Y.: A numerical modelling study on regional mercury budget for eastern North America, Atmos. Chem. Phys., 3, 535-548, doi:10.5194/acp-3-535-2003, 2003.

Lindberg, S., Bullock, R., Ebinghaus, R., Engstrom, D., Feng, X., Fitzgerald, W., Pirrone, N., Prestbo, E., and Seigneur, C.: A synthesis of progress and uncertainties in attributing the sources of mercury in deposition, Ambio, 36, 19-32, 2007.

Marsik, F. J., Keeler, G. J., and Landis, M. S.: The drydeposition of speciated mercury to the Florida Everglades: 
Measurements and modeling, Atmos. Environ., 41, 136-149, doi:10.1016/j.atmosenv.2006.07.032, 2007.

Mason, R. P. and Sheu, G. R.: Role of the ocean in the global mercury cycle, Global Biogeochem. Cy., 16, 1093, doi:10.1029/2001gb001440, 2002.

Mason, R. P., Rolfhus, K. R., and Fitzgerald, W. F.: Mercury in the North Atlantic, Mar. Chem., 61, 37-53, doi:10.1016/S03044203(98)00006-1, 1998.

Mason, R. P., Lawson, N. M., and Sheu, G. R.: Mercury in the Atlantic Ocean: factors controlling air-sea exchange of mercury and its distribution in the upper waters, Deep-Sea Res. Pt. II, 48, 2829-2853, doi:10.1016/S0967-0645(01)00020-0, 2001a.

Mason, R. P., Sheu, G. R., and Lawson, N. M.: Redox chemistry of mercury at the air-water interface and its role in the global cycling of mercury, Abstr. Pap. Am. Chem. S, 222, U429-U429, 2001b.

Millhollen, A. G., Gustin, M. S., and Obrist, D.: Foliar mercury accumulation and exchange for three tree species, Environ. Sci. Technol., 40, 6001-6006, doi:10.1021/Es0609194, 2006.

Morel, F. M. M., Kraepiel, A. M. L., and Amyot, M.: The chemical cycle and bioaccumulation of mercury, Annu. Rev. Ecol. Syst., 29, 543-566, doi:10.1146/annurev.ecolsys.29.1.543, 1998.

Myers, R. H., Montgomery, D. C., and Anderson-Cook, C. M.: Response Surface Methodology: Process and Product Optimization Using Designed Experiments, 3 Edn., Wiley Series in Probability and Statistics, John Wiley \& Sons Inc., New York, 704 pp., 2009.

Obrist, D., Johnson, D. W., Lindberg, S. E., Luo, Y., Hararuk, O., Bracho, R., Battles, J. J., Dail, D. B., Edmonds, R. L., Monson, R. K., Ollinger, S. V., Pallardy, S. G., Pregitzer, K. S., and Todd, D. E.: Mercury Distribution Across 14 US Forests. Part I: Spatial Patterns of Concentrations in Biomass, Litter, and Soils, Environ. Sci. Technol., 45, 3974-3981, doi:10.1021/Es104384m, 2011.

Pacyna, E. G., Pacyna, J. M., Steenhuisen, F., and Wilson, S.: Global anthropogenic mercury emission inventory for 2000, Atmos. Environ., 40, 4048-4063, doi:10.1016/j.atmosenv.2006.03.041, 2006.

Pacyna, J. M., Pacyna, E. G., Steenhuisen, F., and Wilson, S.: Mapping 1995 global anthropogenic emissions of mercury, Atmos. Environ., 37, 109-117, doi:10.1016/S1352-2310(03)00239-5, 2003.

Pirrone, N., Cinnirella, S., Feng, X., Finkelman, R. B., Friedli, H. R., Leaner, J., Mason, R., Mukherjee, A. B., Stracher, G. B., Streets, D. G., and Telmer, K.: Global mercury emissions to the atmosphere from anthropogenic and natural sources, Atmos. Chem. Phys., 10, 5951-5964, doi:10.5194/acp-10-59512010, 2010.

Poissant, L., Amyot, M., Pilote, M., and Lean, D.: Mercury water-air exchange over the Upper St. Lawrence River and Lake Ontario, Environ. Sci. Technol., 34, 3069-3078, doi:10.1021/Es990719a, 2000.

Poissant, L., Pilote, M., Yumvihoze, E., and Lean, D.: Mercury concentrations and foliage/atmosphere fluxes in a maple forest ecosystem in Quebec, Canada, J. Geophys. Res.-Atmos., 113, D10307, doi:10.1029/2007jd009510, 2008.

Pongprueksa, P., Lin, C. J., Lindberg, S. E., Jang, C., Braverman, T., Bullock, O. R., Ho, T. C., and Chu, H. W.: Scientific uncertainties in atmospheric mercury models III: Boundary and initial conditions, model grid resolution, and
$\mathrm{Hg}$ (II) reduction mechanism, Atmos. Environ., 42, 1828-1845, doi:10.1016/j.atmosenv.2007.11.020, 2008.

Qureshi, A., O’Driscoll, N. J., MacLeod, M., Neuhold, Y. M., and Hungerbuhler, K.: Photoreactions of Mercury in Surface Ocean Water: Gross Reaction Kinetics and Possible Pathways, Environ. Sci. Technol., 44, 644-649, doi:10.1021/Es9012728, 2010.

Rutter, A. P., Schauer, J. J., Shafer, M. M., Creswell, J., Olson, M. R., Clary, A., Robinson, M., Parman, A. M., and Katzman, T. L.: Climate Sensitivity of Gaseous Elemental Mercury Dry Deposition to Plants: Impacts of Temperature, Light Intensity, and Plant Species, Environ. Sci. Technol., 45, 569-575, doi:10.1021/es102687b, 2011.

Scholtz, M. T., Van Heyst, B. J., and Schroeder, W.: Modelling of mercury emissions from background soils, Sci. Total Environ., 304, 185-207, doi:10.1016/s0048-9697(02)00568-5, 2003.

Selin, N. E. and Jacob, D. J.: Seasonal and spatial patterns of mercury wet deposition in the United States: Constraints on the contribution from North American anthropogenic sources, Atmos. Environ., 42, 5193-5204, doi:10.1016/j.atmosenv.2008.02.069, 2008.

Shetty, S. K., Lin, C. J., Streets, D. G., and Jang, C.: Model estimate of mercury emission from natural sources in East Asia, Atmos. Environ., 42, 8674-8685, doi:10.1016/j.atmosenv.2008.08.026, 2008.

Smith-Downey, N. V., Sunderland, E. M., and Jacob, D. J.: Anthropogenic impacts on global storage and emissions of mercury from terrestrial soils: Insights from a new global model, J. Geophys. Res.-Biogeo., 115, G03008, doi:10.1029/2009jg001124, 2010.

Soerensen, A. L., Sunderland, E. M., Holmes, C. D., Jacob, D. J., Yantosca, R. M., Skov, H., Christensen, J. H., Strode, S. A., and Mason, R. P.: An Improved Global Model for Air-Sea Exchange of Mercury: High Concentrations over the North Atlantic, Environ. Sci. Technol., 44, 8574-8580, doi:10.1021/Es102032g, 2010.

Stamenkovic, J. and Gustin, M. S.: Nonstomatal versus Stomatal Uptake of Atmospheric Mercury, Environ. Sci. Technol., 43, 1367-1372, doi:10.1021/es801583a, 2009.

Streets, D. G., Hao, J. M., Wu, Y., Jiang, J. K., Chan, M., Tian, H. Z., and Feng, X. B.: Anthropogenic mercury emissions in China, Atmos. Environ., 39, 7789-7806, doi:10.1016/j.atmosenv.2005.08.029, 2005.

Streets, D. G., Zhang, Q., and Wu, Y.: Projections of Global Mercury Emissions in 2050, Environ. Sci. Technol., 43, 2983-2988, doi:10.1021/Es802474j, 2009.

Strode, S. A., Jaegle, L., Selin, N. E., Jacob, D. J., Park, R. J., Yantosca, R. M., Mason, R. P., and Slemr, F.: Air-sea exchange in the global mercury cycle, Global Biogeochem. Cy., 21, Gb1017, doi:10.1029/2006gb002766, 2007.

Sutton, M. A., Nemitz, E., Erisman, J. W., Beier, C., Bahl, K. B., Cellier, P., de Vries, W., Cotrufo, F., Skiba, U., Di Marco, C., Jones, S., Laville, P., Soussana, J. F., Loubet, B., Twigg, M., Famulari, D., Whitehead, J., Gallagher, M. W., Neftel, A., Flechard, C. R., Herrmann, B., Calanca, P. L., Schjoerring, J. K., Daemmgen, U., Horvath, L., Tang, Y. S., Emmett, B. A., Tietema, A., Penuelas, J., Kesik, M., Brueggemann, N., Pilegaard, K., Vesala, T., Campbell, C. L., Olesen, J. E., Dragosits, U., Theobald, M. R., Levy, P., Mobbs, D. C., Milne, R., Viovy, N., Vuichard, N., Smith, J. U., Smith, P., Bergamaschi, P., Fowler, D., 
and Reis, S.: Challenges in quantifying biosphere-atmosphere exchange of nitrogen species, Environ. Pollut., 150, 125-139, doi:10.1016/j.envpol.2007.04.014, 2007.

USEPA: User's guide for evaluating subsurface vapor instrusion into buildings (User's Guide), Washington, DC, U.S. Environmental Protection Agency, 2004.

Xu, X. H., Yang, X. S., Miller, D. R., Helble, J. J., and Carley, R. J.: Formulation of bi-directional atmosphere-surface exchanges of elemental mercury, Atmos. Environ., 33, 4345-4355, doi:10.1016/S1352-2310(99)00245-9, 1999.

Yin, R. S., Feng, X. B., and Meng, B.: Stable Mercury Isotope Variation in Rice Plants (Oryza sativa L.) from the Wanshan Mercury Mining District, SW China, Environ. Sci. Technol., 47, 22382245, doi:10.1021/Es304302a, 2013.

Zehner, R. E. and Gustin, M. S.: Estimation of mercury vapor flux from natural substrate in Nevada, Environ. Sci. Technol., 36, 4039-4045, doi:10.1021/Es015723c, 2002.

Zhang, H. and Lindberg, S. E.: Sunlight and iron(III)-induced photochemical production of dissolved gaseous mercury in freshwater, Environ. Sci. Technol., 35, 928-935, doi:10.1021/Es001521p, 2001.

Zhang, L., Brook, J. R., and Vet, R.: A revised parameterization for gaseous dry deposition in air-quality models, Atmos. Chem. Phys., 3, 2067-2082, doi:10.5194/acp-3-2067-2003, 2003.

Zhang, L., Wright, L. P., and Blanchard, P.: A review of current knowledge concerning dry deposition of atmospheric mercury, Atmos. Environ., 43, 5853-5864, doi:10.1016/j.atmosenv.2009.08.019, 2009a.
Zhang, L., Blanchard, P., Gay, D. A., Prestbo, E. M., Risch, M. R., Johnson, D., Narayan, J., Zsolway, R., Holsen, T. M., Miller, E. K., Castro, M. S., Graydon, J. A., Louis, V. L. St., and Dalziel, J.: Estimation of speciated and total mercury dry deposition at monitoring locations in eastern and central North America, Atmos. Chem. Phys., 12, 4327-4340, doi:10.5194/acp-12-43272012, 2012.

Zhang, L. M., Brook, J. R., and Vet, R.: On ozone dry deposition with emphasis on non-stomatal uptake and wet canopies, Atmos. Environ., 36, 4787-4799, doi:10.1016/S1352-2310(02)00567-8, 2002a.

Zhang, L. M., Moran, M. D., Makar, P. A., Brook, J. R., and Gong, S. L.: Modelling gaseous dry deposition in AURAMS: a unified regional air-quality modelling system, Atmos. Environ., 36, $537-$ 560, doi:10.1016/S1352-2310(01)00447-2, 2002b.

Zhang, L. M., Wright, L. P., and Blanchard, P.: A review of current knowledge concerning dry deposition of atmospheric mercury, Atmos. Environ., 43, 5853-5864, doi:10.1016/j.atmosenv.2009.08.019, 2009b.

Zotarelli, L., Dukes, D. M., and Morgan, K. T.: Interpretation of soil moisture content to determine soil field capacuty and avoid over-orrigating sandy soils using soil moisture sensors, The Agricultural and Biological Engineering Department, Florida Cooperative Extension Service, Institute of Food and Agricultural Sciences, University of Florida., AE460, 2010. 